\title{
CENAS PRIMITIVAS
}

HAL FOSTER

PRIMUTVE SCENES

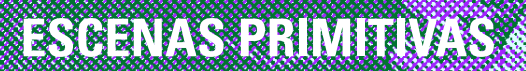


“Negro imundo!” Ou simplesmente: “Olhe, um negro!” Es-

*Universidade de São Paulo (USP), Brasil

Paula Mermelstein

(1) https://orcid.org/0000 $\underline{0002-5938-4366}$

**Universidade de São Paulo (USP), Brasil

https://doi.org/10.11606/ issn.2178-0447. ars.2021.192811

1. Tradução do texto "Primitive" Scenes, publicado na Critical Inquiry, vol. 20, n. 1 (outono,

1993), pp. 69-102, The

University of Chicago Press.

2. Pelos conselhos a respeito deste texto, agradeço ao Sander

Gilman; aos participantes do meu seminário “Cenas 'primitivas', máquinas de sonhos", na Sociedade para as Humanidades da Universidade de Cornell,

especialmente à Helen Molesworth, ao Blake Stimson e ao Peter Brunt; sas são as primeiras palavras de "A experiência vivida do negro", texto central de Pele negra, máscaras brancas (1952), de Frantz Fanon. Elas resgatam uma cena primária de imposição de identidade que "fixa" Fanon por meio de duas maneiras, ao menos: através do olhar do sujeito branco ("Olhe, um negro") e da associação da negritude com a sujeira ("Negro imundo") (FANON, [1952] 2020, posição 1352). Nas páginas seguintes, eu pretendo considerar esse olhar e essa associação no contexto do primitivismo modernista.

Fanon não é objetificado em qualquer sentido simples: "aos olhos do branco" ele é também privado de "resistência ontológica". Ele não consegue resistir, conforme sugere, porque não se sente coerente: "No mundo branco, o homem de cor encontra dificuldades na elaboração do seu esquema corporal" (Ibidem, posição 1381). O eco de Jacques Lacan é deliberado: através do espelho do homem branco, a formação do Eu do negro encontra-se, em certo sentido, comprometida. Isso ocorre, de acordo com Fanon, porque "por baixo" do seu "esquema corporal" (Ibidem, posição 
1381) é projetado um "esquema histórico-racial" que nele interfere: "milhares de detalhes, anedotas, relatos" (Ibidem, posição 1393) que consentem que ele exista apenas como uma coisa "epidérmica" amputada. "Meu corpo me era devolvido desmembrado, desmantelado, arrebentado, todo enlutado naquele dia branco de inverno" (Ibidem, posição 1423). A esse sujeito violado, resta recolher os pedaços, e Fanon toma para si a tarefa psicopolítica de reordená-los em um "esquema" absolutamente distinto.

Eis o trauma dessa cena primária da "negritude". Mas e quanto ao pequeno garoto que não somente está presente na cena, mas também a provoca com seu choro: "Mamãe, olhe o negro, estou com medo!" (Ibidem, posição 1356). E quanto a seu trauma de identidade, sua repentina subjetificação enquanto não negro? Obviamente, não há simetria entre as cenas: o poder nessa fixação é radicalmente desigual; o trauma do garoto é politicamente insignificante. E mesmo assim, deixaremos escapar uma percepção crítica a respeito da subjetividade colonialista representada pelo garoto se o ignorarmos por completo? Se a negritude é um fato - mesmo depois de acolhida e revalorizada como foi pelos movimentos políticos dos anos 1960, ou enquadrada e desconstruída como foi pelo discurso crítico do presente -, ela é também uma fantasia, com evidente 
efetividade enquanto tal. Em "A experiência vivida do negro", Fanon não explora o outro lado dessa fantasia - o que eu espero fazer aqui, não em relação à cena colonialista do garoto com Fanon, mas aos encontros primitivistas de Paul Gauguin, Pablo Picasso e Ernst Ludwig Kirchner com figuras da África e da Oceania.

Assim como Fanon voltou-se à psicanálise quando confrontado com as forças irracionais do racismo colonial, também eu o farei aqui. Um giro como esse, ainda assim, é sempre ambíguo, tanto em termos de raça quanto de gênero, uma vez que a psicanálise não pode ser separada nem de seu contexto imperialista, nem de suas premissas heterossexistas. Certo primitivismo também está inscrito nessa psicanálise, que estabelece correlações entre fantasias de alteridade racial e sexualidade feminina ${ }^{1}$. No entanto, é precisamente porque a psicanálise é, em si, a esfera da fantasia, que ela se torna crucial à crítica do primitivismo - contanto que suas próprias fantasias primitivistas sejam também criticadas.

A imbricação do primitivismo na antropologia, a outra grande ciência da alteridade, é bastante discutida hoje. Uma indústria crítica desenvolveu-se sobre esse terreno, em específico desde que foi realizada no Museu de Arte Moderna em Nova York, em 1984, a exposição “'Primitivism' in Twentieth-Century Art”, que pautava 
“afinidades" entre a arte moderna e a arte tribal. Por razões pouco evidentes, entretanto, a imbricação do primitivismo na psicanálise não é muito comentada. Por primitivismo, refiro-me inicialmente à associação de outros raciais com impulsos instintivos (o legado rousseauniano em Freud) e/ou com conflitos sintomáticos (como no subtítulo de "Totem e Tabu": algumas concordâncias entre a vida psíquica dos homens primitivos e dos neuróticos [1913]). Mas de um modo ao mesmo tempo menos evidente e mais problemático, refiro-me também à associação de povos tribais com ordens pré-genitais do impulso, especialmente com as fases oral e anal - uma associação na qual a genitália é frequentemente correlacionada à civilização enquanto êxito sobre o "primitivo". (Uma das primeiras linhas de "Totem e Tabu" (FREUD, [1913] 2012, p. 10): "assim consideramos os [...] selvagens, cuja vida psíquica tem especial interesse para nós, se nela pudermos reconhecer um estágio anterior e bem conservado de nossa própria evolução") ${ }^{2}$. Qual o papel dessas associações primitivistas em Freud? O quão atrelada está a psicanálise aos discursos racializados do século XIX? De que modo essas conexões se confirmam e/ou são contestadas na arte modernista? E de que modos elas podem persistir na teoria contemporânea? Para outras escolas psicanalíticas, afinal, questões como essas são irrelevantes: há muito 
tempo kleinianos prescindiram das "fases" de desenvolvimento em favor de "posições" estruturais, e lacanianos descartaram as analogias entre o infantil, o neurótico e o "primitivo" como parte pré-teórica do pensamento freudiano. No entanto, um certo primitivismo ainda subjaz em grande parte da teoria psicanalítica e, dado o seu prestígio discursivo, também em grande parte da teoria crítica.

Trata-se de uma questão familiar: como usar e criticar Freud a um só tempo. Nesse caso, abraçarei a concepção de fase, mas não as suas associações com povos tribais. $\mathrm{Ou}$, antes, proponho reverter o fluxo dessa associação: por exemplo, considerar a analidade não como propriedade do "primitivo", mas como projeção de uma subjetividade moderna particular no "primitivo". A questão, então, converte-se não no que consiste a "analidade primitiva", mas no porquê de ela ser projetada enquanto tal - isto é, em compreender de quais desejos e medos essa projeção procede.

Freud também associava os instintos com outros sociais, particularmente com o proletariado. E também essa é uma associação típica de seu tempo, que, além disso, compreendia - do ponto de vista normativo do homem branco burguês - outras figuras, como as mulheres (especialmente as prostitutas) e os judeus, como "primitivas" em seu desenvolvimento psíquico, em sua aptidão moral, 
artística e mesmo em sua capacidade civilizacional ${ }^{3}$. A despeito de sua ambivalência (como judeu, em particular), Freud toma partido dessas associações ideológicas de tal modo que a sublimação dos instintos - como tarefa mesma da arte, como o trabalho mesmo da civilização - não implica senão a sublimação dessas figuras "primitivas”, em um processo através do qual elas são, então, excluídas ${ }^{4}$. De que maneiras essas figuras ameaçam a normatividade branca e masculina? Ou, uma vez que é a ambivalência o que está em jogo aqui, de que formas elas também atraem esse sujeito?

Essa ambivalência, evidentemente, diz respeito à sexualidade e suas origens não remontam nem a Freud, nem, aliás, aos discursos racializados do século XIX. Considere-se o velho binarismo entre o nobre e o ignóbil selvagem. Cruciais para a construção europeia de alteridade, essas figuras estiveram frequentemente divididas entre a Oceania e a África, entre o paraíso sexual dos mares do sul e a sexualidade selvagem do "continente negro" - uma metáfora que Freud mais tarde aplicaria à sexualidade feminina ${ }^{5}$. Essa divisão ainda se mantinha presente no século XIX, agora recodificada em linhas neoclássicas e românticas, sendo o ignóbil selvagem equacionado ao nobre como emblema romântico do nativismo cultural (figura 1). Mesmo até então, o selvagem era entendido de acordo com 
práticas determinadas, especialmente com o canibalismo e o incesto. De fato, ao menos desde Vico, essas práticas “primitivas” fixaram os limites da sociedade humana e, no pensamento moderno, foram teorizadas como tabu por Freud, Lacan, Bataille, Lévi-Strauss e muitos outros. Mas é precisamente enquanto tabus que elas permanecem ambivalentes, como fantasias transgressivas. Isso equivale a dizer que nós, civilizados neuróticos, somos atraídos pela ideia de semelhante gratificação instintiva - pela completa liberdade oral representada pelo canibalismo ou pela liberdade genital total representada pelo incesto - ainda que nos revoltemos diante dela ${ }^{6}$. Nesse sentido, a figura fantasmática do selvagem provoca uma oscilação entre estima e desgosto (com uma inveja delinquente em algum ponto mediano), uma oscilação evidente na própria cisão entre os tipos do nobre e do ignóbil7. 
FIGURA 1.

Jacques Arago, Selvagem da Nova Holanda, c. 1817 - 1823. Litografia, $35 \times 24 \mathrm{~cm}$. British Museum of Art, Londres.

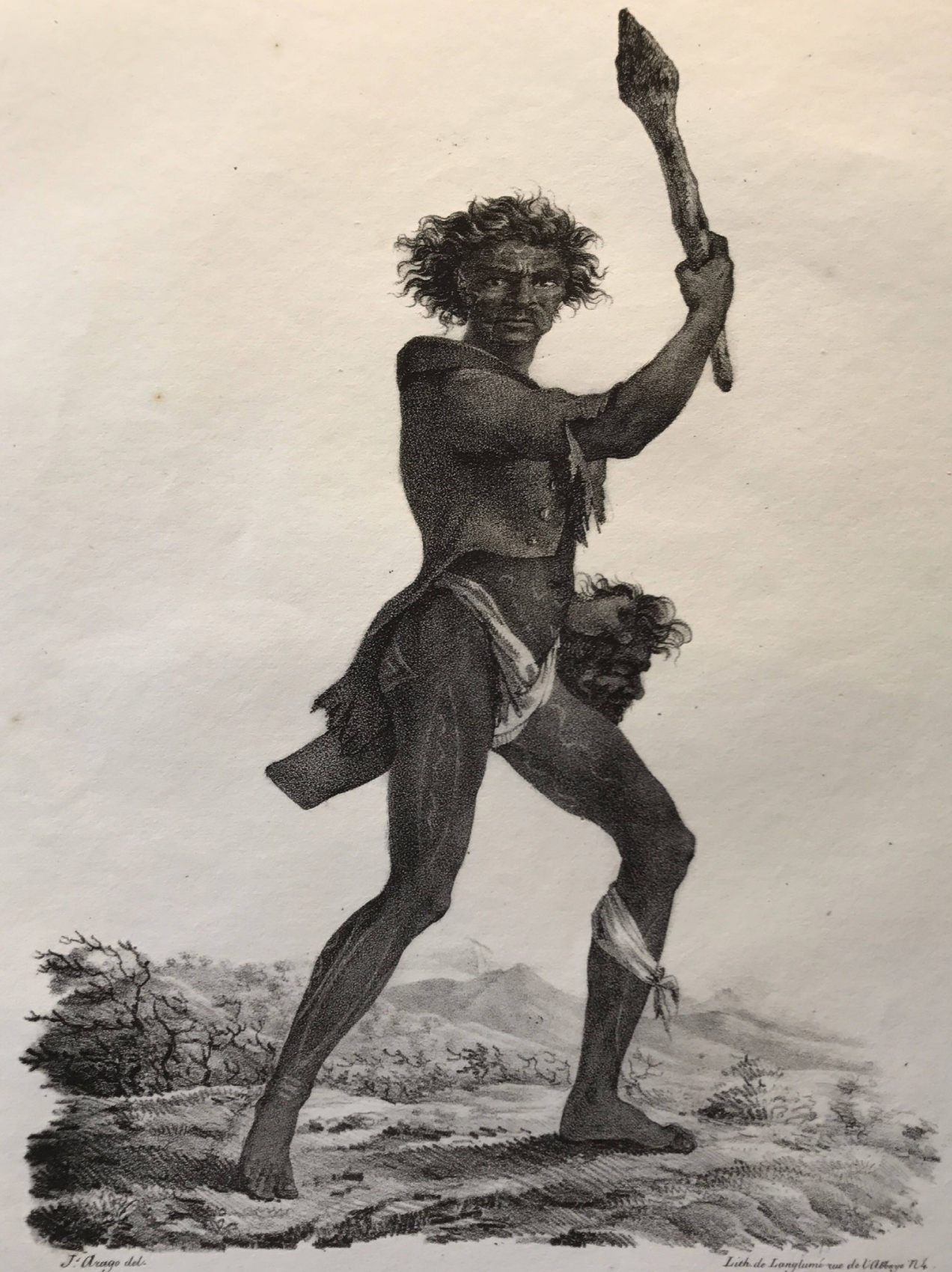

$$
\begin{aligned}
& \text { Saunage de la Pouvelle-tidlande } \\
& \text { senant de combaure. } \\
& \text { (Port Jacksen.) }
\end{aligned}
$$

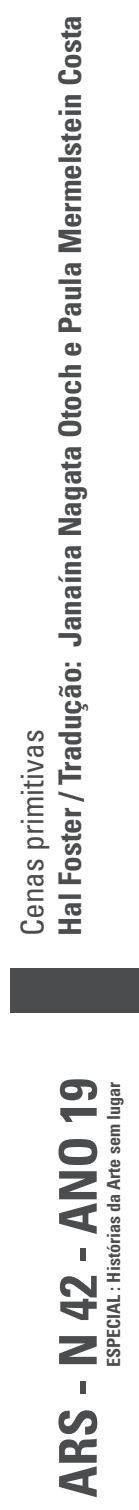

1589 
E o que isso tem a ver com o modernismo? Parece-me que fantasias similares também atravessam o seu primitivismo. E mais: que elas alcançam um ponto crítico - um ponto de crise de uma construção particular de masculinidade - nas "cenas primitivas” de Gauguin, Picasso e Kirchner. Utilizo “cenas primitivas” aqui para que ressoem nas "cenas primárias", isto é, nas cenas em que, de acordo com Freud, a criança testemunha ou confabula o sexo parental, ou, de modo geral, nas cenas em que cada um de nós descobre suas próprias origens - como, de certo modo, Gauguin descobre as suas durante o seu summa de 1897, em uma pintura feita no momento de sua tentativa de suicídio, na qual ele se indaga sobre sua identidade no campo de seu outro: De onde viemos, o que somos, para onde vamos? (figura 2). Para Freud, questões como essas também envolvem outras fantasias primárias e origens traumáticas: a origem da sexualidade na fantasia de sedução (será possível que esse trauma de alguma forma seja trabalhado em outra pintura fundamental de Gauguin, Espírito dos mortos assistindo [1892], uma imagem de sua jovem amante Tehamana?) ou a origem da diferença sexual na fantasia da castração (e será que esse trauma de alguma forma é tratado por Picasso em sua célebre Les Demoiselles d'Avignon [figura 3]?). Para Freud, essas fantasias sobre a origem 
da identidade, sexualidade e gênero constantemente confundemse em nossa vida psíquica, como ocorre também nas cenas "primitivas" que me interessam.

FIGURA 2.

Paul Gauguin, De onde viemos,

o que somos, para onde vamos?, 1897. Óleo sobre tela $139 \mathrm{~cm} \times 375 \mathrm{~cm}$. Museum of Fine Arts, Boston.

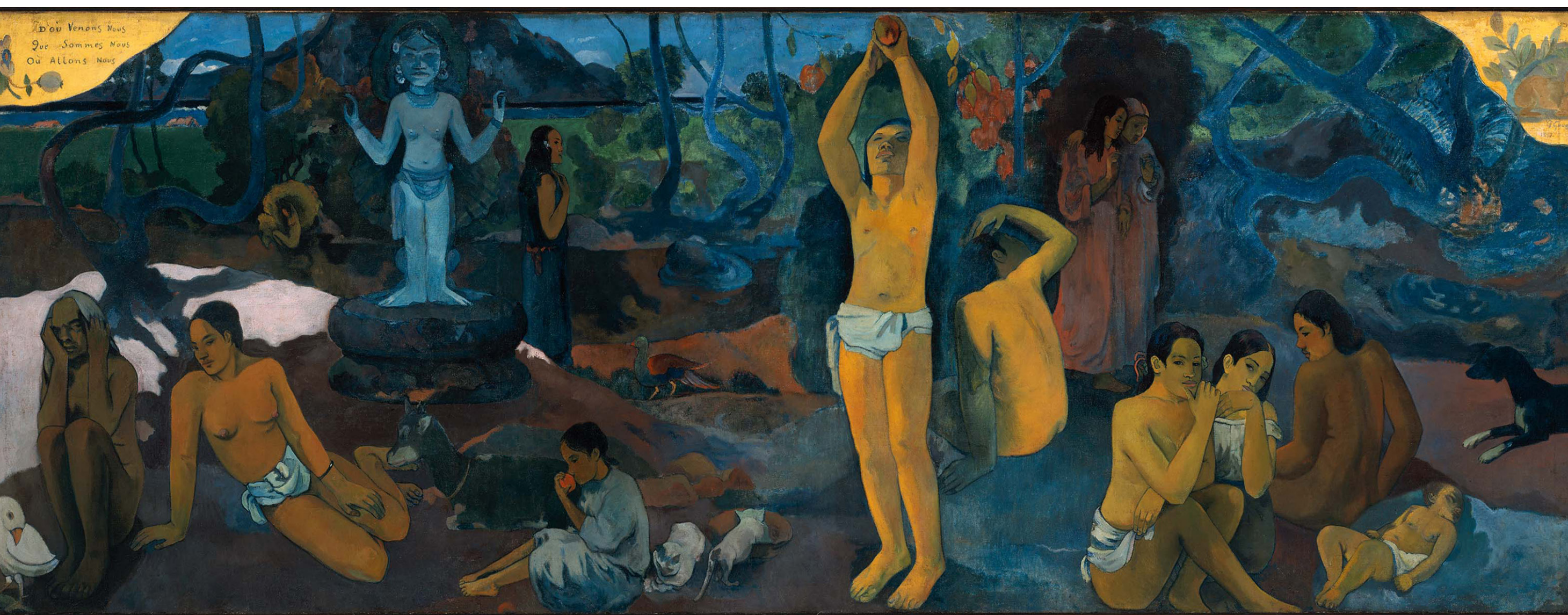


A origem em questão aqui é múltipla. Em um certo nível, ela está relacionada ao encontro de um estilo, frequentemente articulado em torno de um trabalho específico - sendo a proclamação de uma origem estilística um tropo familiar nos manifestos e memórias do alto modernismo. Em outro nível, essa origem envolve o encontro de um sujeito $^{8}$; de fato, a inauguração de um estilo frequentemente apela a um tal encontro subjetivo. A ambiguidade entre essas duas origens é irredutível: amiúde ocorre como se a inauguração estilística estruturasse a origem subjetiva retrospectivamente, ainda que a origem subjetiva impulsione a inauguração estilística a acontecer ${ }^{9}$.

Nessas cenas, então, artistas como Gauguin e Picasso destrincham a identidade em termos tanto psíquicos quanto artísticos, e o fazem em um momento em que corpos e psiques eram transformados por encontros imperialistas e técnicas industriais ${ }^{10}$. Uma e outra vez, eles mapeiam o racial em torno da diferença sexual e vice-versa, em um dilema de oposições entre branco e preto, feminino e masculino, natureza e cultura, homossexualidade e heterossexualidade. Entretanto, uma vez que a ambivalência governa esse ato de mapear - uma vez que o primitivo ao mesmo tempo atrai e repele os artistas e uma vez que eles desejam e se identificam com 
ele, simultaneamente -, essas oposições são pressionadas até um ponto em que começam a vacilar, no qual a masculinidade branca e heterossexual fundada nessas oposições cede a fissuras.

Eu gostaria de enfatizar essas fissuras com o intuito de interrogar certos pressupostos sobre o domínio masculinista da vanguarda primitivista. Ressaltar a fragilidade do domínio primitivista, seus alicerces no desejo e na fantasia, porém, não equivale a desmerecer sua atualidade, nem a minimizar a efetividade das relações de poder ou os efeitos da dominação no encontro imperialista. A vanguarda primitivista foi politicamente ambígua, para dizer o mínimo; e embora ela explorasse novos objetos, imagens e posições subjetivas inaugurados pela dinâmica industrial-imperialista da modernidade, ela operava através das resistências que essa dinâmica provocava. De todo modo, essa vanguarda também era ambivalente quanto às suas posições críticas. Em sua identificação com o "primitivo" não obstante figurado como negro, feminino, libertino -, persistia uma desidentificação com a sociedade branca, patriarcal e burguesa. Por mais problemática que soe essa identificação hoje para nós, tal desidentificação não deve ser desconsiderada. 
Com o propósito de lançar luz sobre a crise da masculinidade que vejo no encontro primitivista, gostaria de recorrer ao clássico texto sobre a cena primária em Freud, "História de uma neurose infantil", o caso do "Homem dos lobos" de 1914-15 (publicado em 1918) - um texto mais ou menos contemporâneo de algumas das imagens e histórias que me interessam aqui. Esse caso de análise de um jovem aristocrata russo recebeu atenção privilegiada da teoria crítica, com interpretações bem mais sofisticadas do que minhas próprias considerações prosaicas. Para mim, importa mais tomá-lo como uma desconstrução detalhada de certa subjetividade masculina particular; se esse caso pode ser estendido de modo a abranger outras subjetividades da época - isto é, se o Homem dos lobos é um sujeito tão representativo e, de fato, tão "normal" quanto eu sugiro que ele seja - é uma questão que eu devo deixar em aberto por enquanto.

Como é bem sabido, Freud reporta a neurose do Homem dos lobos a possíveis eventos da primeira infância. Três em particular: o medo de lobos provocado por contos de fadas; uma enigmática sedução pela irmã por volta dos três anos, com o garoto na posição passiva; e uma posterior sedução de sua babá, agora com o menino como agente fálico ativo, mas com a recusa de sua investida. Nesse 
ponto, conforme argumenta Freud, o Homem dos lobos foi "lançado de volta" a uma organização pré-genital dos instintos - a um sadismo anal, especificamente - que se manifesta em uma acentuada crueldade dirigida a empregados e animais (note-se a reveladora associação entre ambos) ${ }^{11}$. O sadismo, além disso, converteu-se também em fantasias masoquistas de autoflagelo. E assim se desenvolveu a ambivalência característica do Homem dos lobos: como uma oscilação entre as posições ativa e passiva, entre cenas masoquistas e sádicas, desencadeadas mais intensamente vis-à-vis com seu pai. Em seu modo ativo, o Homem dos lobos se identificava com o pai, enquanto em seu modo passivo ele o desejava, isto é, desejava ser o seu objeto de desejo.

Nesse momento, o célebre sonho (que remonta aos seus quatro anos de idade) é apresentado junto a um desenho (figura 4). O menino sonha com seis ou sete lobos em uma árvore (embora, no desenho, apareçam apenas cinco), todos completamente imóveis, com caudas espessas, encarando-no silenciosamente. Freud relaciona os vestígios desse sonho ansioso à antiga fobia do garoto por lobos, alimentada pela imaginação dos contos de fadas de sua infância. Esses vestígios, entretanto, foram virados do avesso pelo trabalho do sonho: as caudas excessivamente robustas 
indicam ausência completa de caudas, isto é, a castração; o olhar silencioso dos lobos, seu próprio olhar fixo diante da cena primária; e a imobilidade dos lobos, a travessura sexual de seus pais. Em síntese, o sonho reelabora a cena primária propriamente dita (que remonta a um ano e meio de idade): um coitus a tergo, por trás, com os genitais de ambos, o pai e a mãe, expostos. Assim deve ser, necessariamente, segundo Freud, para que o garoto possa perceber que à sua mãe falta o pênis.

Essa (re)construção está sujeita a muitas críticas, especialmente por ser uma (re)construção. Para Freud, entretanto, a ambiguidade do evento como real e/ou imaginado é fundamental para o efeito a posteriori (Nachträglichkeit) ${ }^{12}$ do trauma. $O$ garoto não consegue compreender a cena até que suas indagações sobre a própria sexualidade comecem. É nesse contexto que ele recorda ter sonhado (aos quatro anos) e, só então, que ele se lembra de seu pai ereto como um lobo e de sua mãe "curvada, como os animais". Significativamente, Freud ([1918] 2010, p. 54) denomina essa posição de more ferarum, "a forma filogeneticamente mais antiga" (Ibidem, p. 58). De modo implícito, é “o primitivo" (ao invés do animal, de acordo com sua correlação evolucionista entre a vida sexual dos indivíduos e a das espécies) o que lhe serve 
como a referência desse estágio pregresso ou dessa regressão psicossexual (outra vez, "o selvagem" aparece como uma figura "do estágio anterior e bem conservado de nossa própria evolução") ${ }^{13}$. Essa posição provoca um erotismo anal duradouro no Homem dos lobos, o que o torna "primitivo" para Freud. De fato, essa posição "primitiva", essa cena primária, "fragmenta" a identidade sexual do menino, dividindo-o entre o amor pelo pai e a ansiedade em torno da castração necessária para a consumação desse amor. É essa ansiedade que é figurada nos lobos do sonho, cujos olhares ameaçam o próprio olhar do garoto (para Freud, o temor à cegueira é uma metáfora familiar da castração).

A análise não termina aí e jamais se conclui para esse analisando experiente que só renuncia ao divã para deitar-se no leito de morte. Mas os pontos mais significativos para minha argumentação estão situados: em face do medo da castração ou de uma crise genital, tem lugar uma regressão para a ordem pré-genital, na qual o sujeito oscila entre um erotismo anal, um modo passivo masoquista (associado, como de costume em Freud, com o feminino e o homossexual), e seu complemento ativo, um sadismo anal - uma oscilação expressiva de uma enorme ambivalência da posição psicossexual ${ }^{14}$. 
Não tenho a intenção de impor esse perfil a Gauguin, Picasso e Kirchner, patologizando-os ou psicologizando a arte, mas eu acredito, sim, ser proveitoso aproximar-se da ambivalência primitivista nesses termos. É sempre um risco transitar muito rapidamente do registro inconsciente ao trabalho de arte, de modo a ocluir tanto as mediações formais quanto as dimensões sociais das decodificações primitivistas de raça e sexualidade ${ }^{15}$. É também um risco misturar artista e observador em um psicologismo que é, ao mesmo tempo, demasiado generalista e demasiado exclusivista, de forma a ocultar as diferenças históricas implicadas nessas decodificações. Como especificar a ambivalência na obra de arte? Ela permanece de algum modo imanente ou é apenas ativada quando encaramos a imagem? Ao menos um ponto é certo: a ambivalência do encontro primitivista excede a psique do artista individualmente. Na verdade, essa ambivalência já encontra-se ativa em duas tradições fundamentais sobre as quais esses artistas trabalham: a vanguardista e a exotista.

Comecemos pela tradição vanguardista. Um signo da sexualidade na Europa no século XIX era o da serviçal negra, representada de modo célebre na Olympia (1863) de Manet - uma imagem significativa tanto para Gauguin quanto para Picasso e Kirchner ${ }^{16}$. Em um texto seminal, Sander Gilman relacionou a figura dessa serviçal 
à da "Hottentot Venus", um corpo fantasmático urdido por imagens exageradas personificado na figura da africana Sarah Baartman. Conforme demonstra Gilman, essa "Vênus" inscrevia no corpo feminino uma sexualidade negra excessiva, particularmente plasmada no signo de grandes nádegas (figura 5) ${ }^{17}$. O atributo de uma sexualidade negra ameaçadora foi frequentemente transfigurado na imagem da mulher prostituta, como Gilman evidencia através da justaposição da "Vênus" e de Nana (1877), também de Manet. Essa transfiguração, por sua vez, foi o que deu sustento à fusão entre o "primitivo" e a prostituta, compulsiva e indistintamente repetida seja em departamentos de polícia, seja em ateliês de vanguarda. Les Demoiselles d'Avignon é apenas mais um derradeiro exemplo dessa representação perfeita, nas palavras de Baudelaire, "da selvageria na civilização"18. Menina dos olhos da competição homossocial do alto modernismo, essa imagem filtrou-se através de diferentes temperamentos e estilos, do suave Matisse ao feroz Kirchner.

Mobilizar essas figuras de alteridade racial, sexual e social em moldes anais e poses bestiais é, sem dúvida, reduzir a mulher à natureza, em um gesto pictórico de sujeição sexual, conforme denunciaram as críticas feministas de Carol Duncan a Griselda Pollock e Abigail Solomon-Godeau. Mas seriam imagens como 
Espirito dos mortos assistindo (figura 6) ou Les Demoiselles d'Avignon apenas a mais pura expressão de domínio masculinista? Ou não seriam elas também uma fantasia compensatória indicativa da ameaça de perda de tal domínio? Um sujeito em pleno domínio faz gestos agressivos de modo tão ansioso, ou não se trata de efetuar imagens eivadas de ambivalência - executadas, quem sabe, para manter o controle, embora nunca completamente? Uma crítica que não dê vazão a essa ambivalência corre o risco de simplificar, ou mesmo totalizar, e, assim, focalizar, ou mesmo afirmar uma construção particular da masculinidade branca. Isto é, de considerar inadvertidamente o desejo por domínio como domínio em si, de conceder a essa masculinidade o falo que ela nunca teve ${ }^{19}$.

FIGURA 3.

(NA PÁG SEGUINTE)

Paul Gauguin, Espírito dos mortos assistindo, 1892. Óleo sobre tela, 116,05 × 134,62 cm. Albright Knox Art Gallery,

Nova York. 


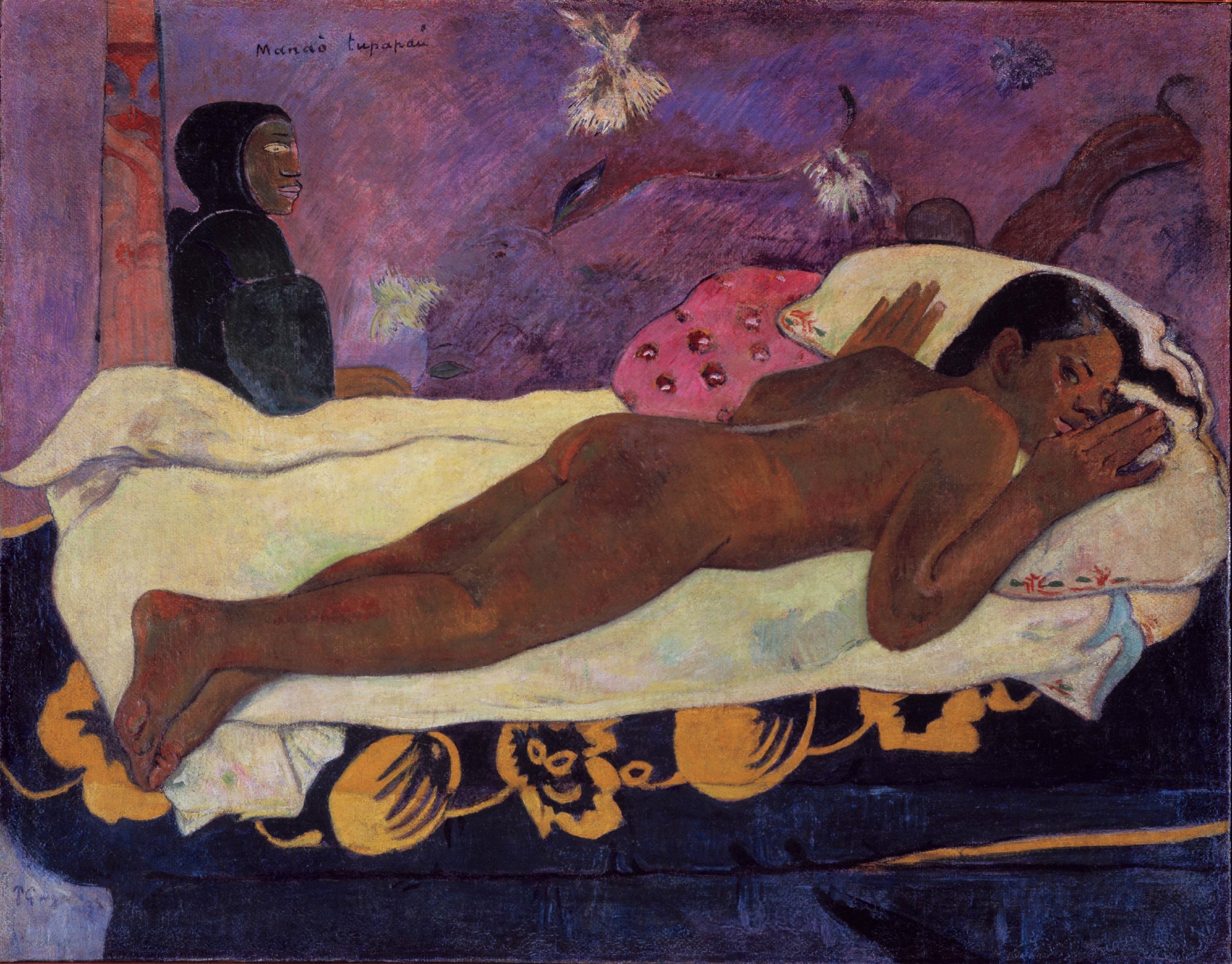

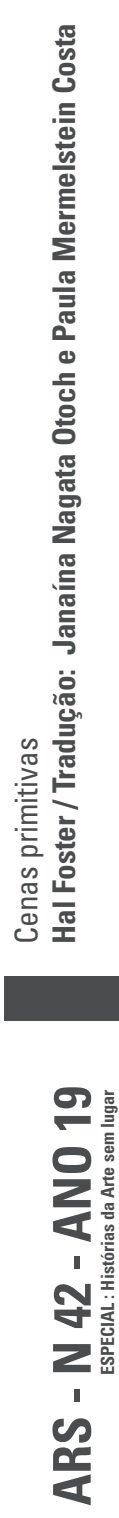

1601 
A ambivalência em relação ao primitivo-prostituta é, no mínimo, dúplice. Em primeiro lugar, essa ambivalência expressa uma figura a um só tempo de desejo e identificação, de controle e redenção. Picasso posiciona o observador masculino (sendo ele mesmo o primeiro) para dominar suas demoiselles ou para ser dominado por elas? Em segundo lugar, tal ambivalência é ainda a figura de uma nova valorização, mas também de uma antiga degradação do "primitivo", que, mesmo quando elevado a um lugar privilegiado nessa arte, permanece como signo psicossexual primário. Essa ambivalência, essa fantasia sexual, é o que eu gostaria de examinar através do modelo analítico detalhado do caso do Homem dos lobos - de erotismo e sadismo anal embaralhados.

Esse complexo tampouco é alheio à outra tradição que prepara o solo para o modernismo primitivista: a tradição do exotismo. Frequentemente, na arte orientalista, e às vezes na arte japonista, o outro racial, masculino ou feminino, é apresentado como passivo, disponível para o observador masculino. O olhar colonialista parece duplicar o olhar sexual em uma visão de domínio masculinista. Entretanto, é possível que nem aqui esse domínio esteja seguro: caso estivesse, seria necessário apelar a tais representações? $\mathrm{O}$ teatro visual orientalista opera sobre impulsos constituintes tais 
como voyeurismo e exibicionismo, sadismo e masoquismo, através de diferentes conteúdos e estilos, como atestam duas de suas mais célebres instâncias. Considere-se o romantismo sensual de $A$ morte de Sardanapalus (1827), de Eugène Delacroix (figura 7), uma cena de sadomasoquismo (se é que ela alguma vez existiu), e a ilusionística e voyeurista $O$ encantador de serpentes (fins de 1860), de Jean-León Gérôme (figura 8). A pintura de Delacroix oferece uma fantasia erótica e despótica de um harém em uma orgia de morte, enquanto a de Gérôme oferece uma promessa erótica anunciada pelo próprio título. No caso de Delacroix, trata-se de uma fantasia de poder absoluto $e$ submissão abjeta (a segunda fantasia que reassegura que seus contemporâneos europeus ainda estavam ansiosos quanto à figura do rei; o todo-poderoso prestes a ser deposto) ${ }^{20}$. No caso de Gérôme, trata-se de uma cena homoerótica projetada no exótico, onde o homoerotismo pode ser tanto desfrutado em esfera privada quanto publicamente denunciado como prática de um outro imoral, que necessita de correção colonialista (uma moral correlata pode ser igualmente extraída de Morte de Sardanapalus) ${ }^{21}$. Em suma, mesmo quando a pintura orientalista pretende reassegurar o observador masculino europeu, pode haver uma cisão ambivalente, precisamente devido ao apelo direcionado à fantasia erótica. Eixos 
de identificação e desejo podem tangenciar-se, e as posições do masculino e do feminino, do ativo e do passivo, podem se entrecruzar.

FIGURA 4.

Eugène Delacroix, $A$ morte de Sardanapalus, 1827. Óleo sobre tela, $392 \times 496 \mathrm{~cm}$. Museu do Louvre, Paris

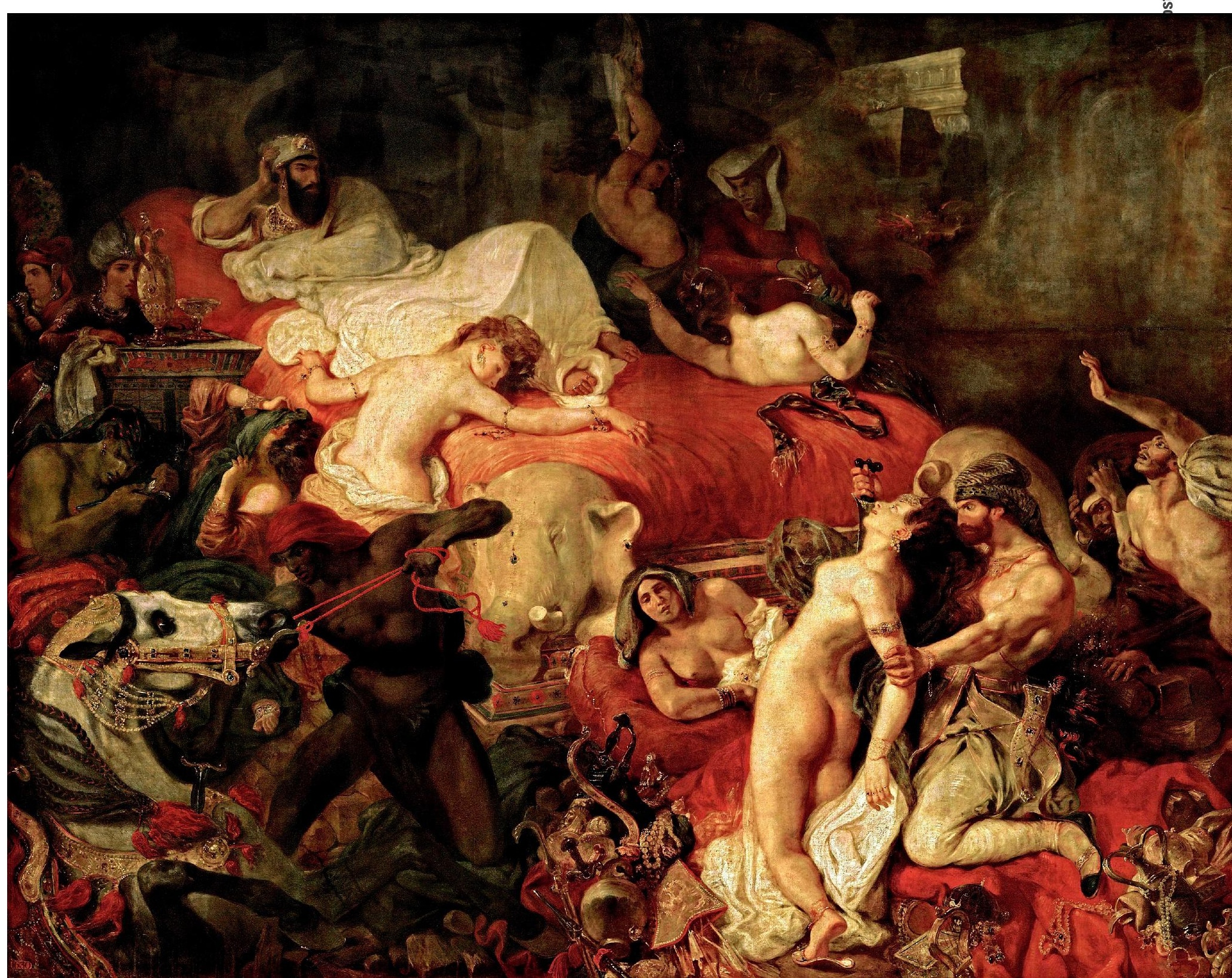


escritos), assim como a ambivalência centrada no erotismo anal. Por um lado, existe o desejo explícito de romper com as oposições culturais entre o Europeu e o "primitivo" - entre a repressão branca e a sexualidade negra, entre cultura e natureza. Um desejo de romper com as oposições psíquicas mantidas para sustentar as oposições culturais: ativo e passivo, masculino e feminino, heterossexual e homossexual. Por outro lado, existe uma insistência reativa nessas oposições, uma aversão a qualquer um desses cruzamentos. Esse conflito ocorre porque o primitivista visa simultaneamente estar aberto à diferença (para ser tomado em êxtase, literalmente fora de si sexualmente, socialmente e racialmente) $e$ ser fixado em oposição ao outro (para ser reestabelecido e reassegurado enquanto sujeito soberano).

É possível especular sobre dois outros pontos a respeito desse conflito. Em primeiro lugar, ele ajuda a compreender a ambiguidade política da persona primitivista. Com um chapéu de cowboy e inspirado em Buffalo Bill, Gauguin, ao mesmo tempo burguês e boêmio, "sensível” e "índio", por exemplo, desembarca no Taiti, onde suas atividades são bem pouco politicamente corretas de qualquer ponto de vista. Em segundo lugar, a própria tensão entre o desejo pela diferença extasiante e a necessidade de 
uma identidade-por-oposição estável pode contribuir para a agressividade frequente no encontro primitivista, uma agressividade que se torna patente com Picasso.

Como, então, interpretar essa ambivalência tal como ela se apresenta nas imagens e histórias desses artistas? É tentador relacioná-la, de início, à cisão psíquica na escolha do objeto masculinista descrita por Freud em seu artigo de 1912 "Sobre a mais comum depreciação na vida amorosa”. Nele, Freud ([1912] 2013, posição 270-284) discute a cisão entre "a corrente terna e a corrente sensual” (Ibidem, posição. 272) que informam a oposição vitoriana familiar entre a Madonna e a prostituta. Para Freud, essa cisão provém de um apego incestuoso à mãe; uma vez que a corrente afetiva se mantém vinculada a ela, a corrente sexual só pode ser liberada se distanciada dela - isto é, se ela for degradada socialmente e, talvez, também, racialmente. Para Freud, essa demanda impulsiona o uso sexual de "mulheres de classes baixas" e (como achei que poderia acrescentar) de mulheres racialmente subordinadas por homens brancos burgueses. De fato, tal cisão parece ativa em Gauguin, assim como em tantos outros (como Flaubert no Egito). Certamente, ele tenta reunir correntes ternas e sensuais em sua arte. Gauguin pintou sua adorada mãe (figura 9) à maneira sensual, escurecida, 
taitiana (ela, de origem peruana, tinha feições um pouco mais claras), utilizando-se de seu rosto para sua Ève Exotique (1890). E então, em um movimento decorrente, ele com frequência figurou mulheres taitianas como Virgens Marias ${ }^{24}$. Mas, ainda que Gauguin as representasse como puras, ele também as utilizava como prostitutas, e seu tratamento de sua esposa dinamarquesa, Mette, é infame.

FIGURA 6.

Paul Gauguin, Retrato da mãe do artista, 1890. Óleo sobre tela, $41 \mathrm{~cm} \times 33 \mathrm{~cm}$. Staatsgalerie Stuttgart, Stuttgart

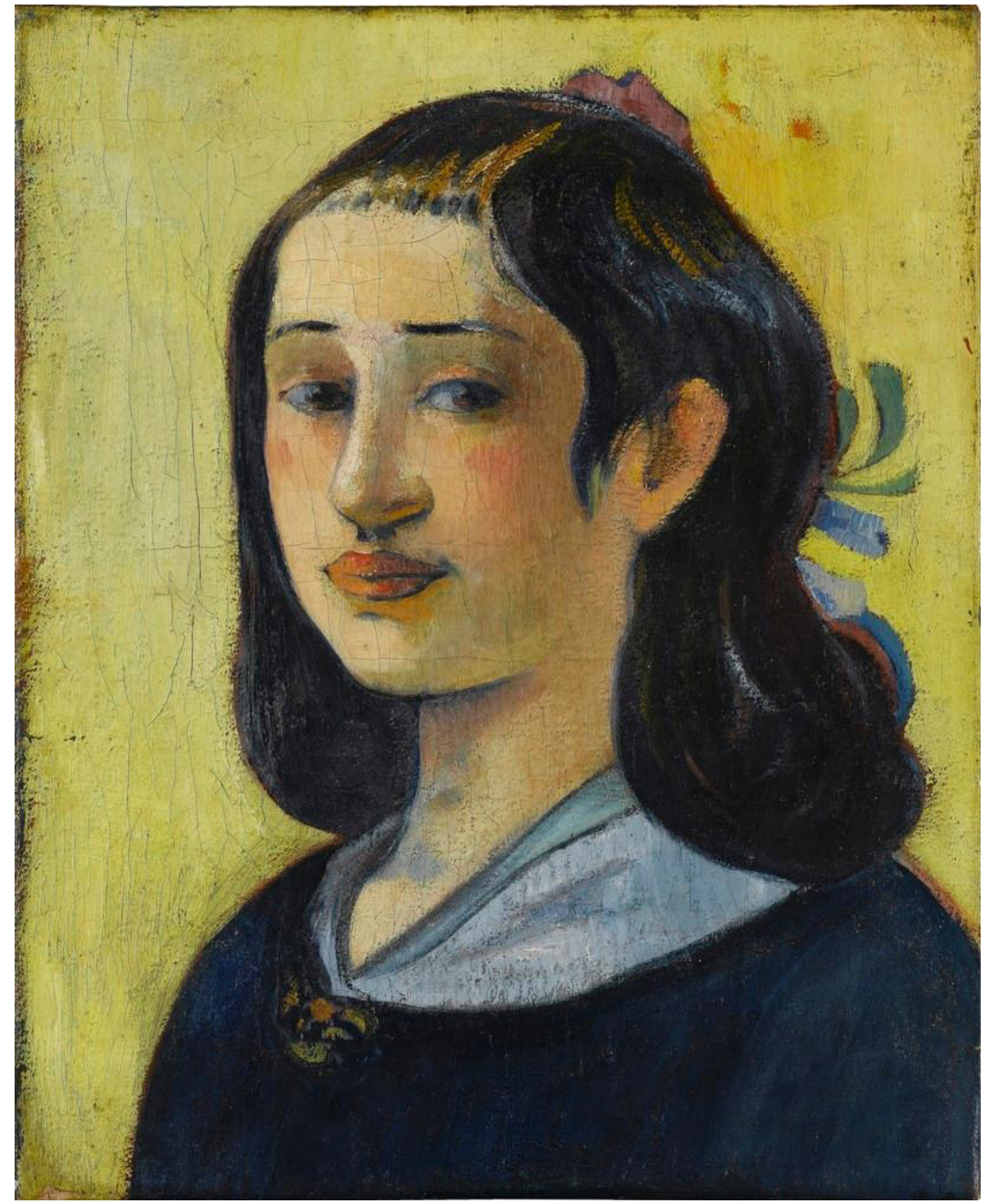

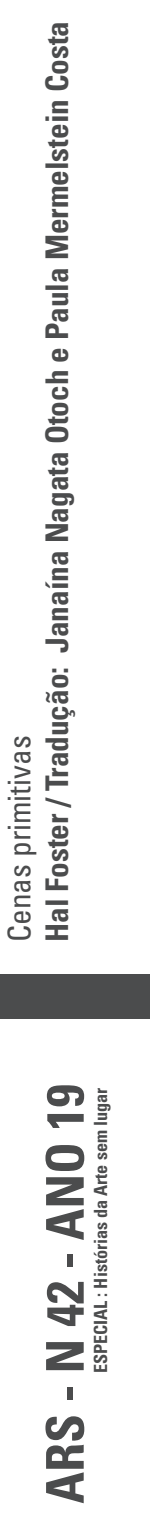

1608 
Uma interpretação como essa, entretanto, não é suficiente por si só. A evidente ambivalência em Gauguin, assim como em Picasso, é mais complicada, menos temática. Não há uma simples cisão de “correntes"; o que está em jogo é uma fissura mais complexa na masculinidade branca heterossexual, em sua ordem genital. Eis a importância, para mim, de um modelo teórico através do qual esse sujeito, quando confrontado com uma ameaça considerada castrativa, é "lançado de volta" para uma fase anal conflituosa, com componentes ativos/sádicos (componentes de domínio sobre o outro) e passivos/masoquistas (componentes de submissão ao outro). Novamente, não se trata de psicologizar a arte, mas apenas de sugerir o núcleo traumático que deve ser parcialmente elaborado para que se possa examinar com cuidado, como uma "criança que desmonta seus brinquedos para fazer outros com os pedaços" (STRINDBERG, [1895] 1999, p. 79).

Creio que minha leitura parecerá menos esquemática caso eu me detenha, agora, nas cenas "primitivas” específicas desses artistas. Eu posterguei essas histórias, as preparei teoricamente, para que elas não fossem tomadas como chaves iconográficas. $\mathrm{Na}$ 
verdade, elas são um tanto suspeitas enquanto considerações e relatos sobre os trabalhos - mas quem, afinal, acredita na autenticidade absoluta desses encontros primitivistas? O que é de fato o mais significativo é que esses artistas urdiram tais mitos de origem, encenaram tais cenas primárias, precisamente no registo melodramático do desejo e do medo. Adeptos como eram Gauguin e Picasso dos romances heróicos, há mais em jogo aqui do que o mito tradicional do grande artista, mais do que a afirmação ex nihilo do típico modernista. Pois a cena "primitiva" é autoperformativa em uma modalidade especial, sendo frequentemente uma fantasia de renascimento situada no campo do outro, de uma maneira que claramente evoca a imaginação imperial em nível interno ${ }^{25}$.

A história de Gauguin provém de Noa Noa, seu diário de memórias de sua primeira estadia no Taiti, em 1893. Ele conta seu rito de passagem para a vida "selvagem", mas descrito como um relato de algumas das consequências psíquicas da distinção anatômica entre diferentes corpos (para parafrasear Freud). Enquanto Gauguin prossegue sua narrativa, eu observarei apenas algumas das reviravoltas em seu posicionamento sexual-racial:

Eu tenho um amigo nativo que vem me assistir toda vez que trabalho [...]. Este jovem era imaculadamente belo, e, nossa relação, muito amistosa. Às 
vezes... ele me fazia perguntas de um jovem selvagem que quer saber uma porção de coisas sobre o amor na Europa, perguntas que frequentemente me embaraçavam. [Aqui ambos os homens são situados como iniciantes.]

Um dia eu precisava encontrar um tronco de pau-rosa [...] para fazer uma escultura. "Para isso," ele me disse, “é preciso subir a montanha...”. Partimos de manhã cedo. As trilhas indígenas no Taiti são difíceis para um europeu: entre duas montanhas que não podem ser escaladas há uma fenda... cachoeira... uma mixórdia de árvores, samambaias monstruosas. [Aqui, o gênero feminino é atribuído à natureza, e Gauguin vê os taitianos como íntimos dela. Mas o posicionamento sexual dos dois homens muda com frequência à medida que eles atravessam o rio.]

Seguimos ambos nus, exceto por nossos pareôs, machado nas mãos, atravessando o rio várias vezes para aproveitar um pedaço de trilha que meu companheiro mais parecia farejar [Note a intimidade do nativo com o olfato pressuposta por Gauguin.] [...] E lá estávamos nós dois, dois amigos, ele um jovem na flor da idade e eu quase um velho, no corpo e na alma, envelhecido pelos vícios da civilização e ilusões perdidas. [Aqui, a identidade compartilhada entre os homens enquanto homens irrompe em diferença cultural - o velho europeu corrupto em contraste com o jovem nativo puro. E essa distinção é demarcada sexualmente: à medida que o nativo se aproxima de uma natureza feminina, ele é destituído de seu gênero.] O corpo dele, flexível como o de um animal, tinha graciosos contornos, e ele caminhava à minha frente sem qualquer definição de sexo. [A essa altura, à margem do manuscrito, Gauguin acrescenta duas notas de pura ambivalência: "1. $\mathrm{O}$ aspecto andrógino do selvagem, a pouca diferenciação de sexos dos animais. 2. A pureza suscitada pela 
visão do nu e a liberdade entre os dois sexos. A maneira como o vício é desconhecido para os selvagens." Essa associação entre o "selvagem”, o animal e o andrógino tem precedentes no primitivismo; com intenções dignificantes, ela é também, claramente, erótica. Enquanto o nativo é desprovido de seu gênero, Gauguin mantém uma posição masculina, mas apenas por um momento.]

Tive uma espécie de pressentimento de crime [...]. E então uma fadiga do papel do homem, tendo que ser sempre forte [...]. Ser por um minuto a criatura mais fraca, que ama e obedece. [Em outra nota, Gauguin esclarece imediatamente: "Desejo, por um instante, de ser fraco, uma mulher." Aparentemente, ele só consegue conceber a passividade como feminina, e, como ambos os homens estão agora nessa posição, a situação só pode ser compreendida como homossexual, isto é, como vício. (Lembrando que ele está atrás do taitiano na trilha.)]

Cheguei mais perto, livre de barreiras, as têmporas palpitando. A trilha havia chegado ao fim e tínhamos que atravessar o rio; meu companheiro virou-se naquele momento, com o seu o peito largo diante de mim. O andrógino havia desaparecido; era um rapaz, afinal de contas; em seus olhos inocentes refletia-se a limpidez da água. [Aqui, Gauguin decide que deve reivindicar uma posição masculinista, uma vez que sua identidade não deve ser abalada, mas reinventada. Essa reformulação é assinalada por um mergulho na água: o toque inocente e singular "nega" a visão decadente e promíscua. Enquanto isso, a natureza permanece codificada como feminina e a iniciação termina com sua violenta penetração, de um modo bem convencional.]...

$\mathrm{Eu}$ adentrei o matagal avidamente [...] o rapaz continuou o seu 
caminho, com aquele olhar límpido. Ele não percebera nada. [O nativo não é mais concebido como feminino ou homossexual - isso já estava perigoso demais -, mas é caracterizado agora por um aspecto infantil. A infantilização do garoto - assim como a codificação feminina da natureza - permite que Gauguin restabeleça sua identidade europeia precisamente no instante em que ele acreditava tê-la perdido. Nesse momento, sua sexualidade denuncia sua base sadomasoquista.]

Alcançamos nosso destino [...]. Nós dois, ambos selvagens, começamos a cortar uma árvore magnífica [...]. Manejei o machado com fúria, as mãos cobertas de sangue enquanto golpeava com o prazer da brutalidade apaziguada, o prazer da destruição - do que, eu não sei. Compassadamente com o barulho do machado, eu cantei: "Arranca pela raiz toda a floresta (de desejos). Arranca em ti o amor por ti mesmo...". Todos os velhos resíduos de minhas emoções civilizadas [estavam] inteiramente destruídos. Eu voltei sereno, sentindo-me a partir de então um homem diferente, um Maori. (GAUGUIN, 1978, pp. 85-87) ${ }^{26}$ 
Gauguin, todavia, só permanece “sereno" em sua diferença por conta de sua posição dominante, jamais devido ao resultado de sua superação. Ele acredita ter sublimado o "selvagem" (externo e interno), cujas "linhas graciosas" ele pode enfim "admirar" e esculpir “em paz”. Mas essa paz é ilusória: sua ambivalência nunca é resolvida temática ou formalmente. Na verdade, ela se manifesta na própria heterogeneidade estilística de sua obra, com todas as suas referências culturais diversificadas, esquemas de cor dissonantes e construções espaciais bizarras. Ela é, assim “como os sonhos e assim como tudo mais na vida, feita de pedaços" (GAUGUIN, 1963, p. 1).

Tal ambivalência pode, entretanto, ser situada tão diretamente na arte? Ela não se encontraria melhor mediada, digamos, no ideal sinestésico de Gauguin, em sua oscilação entre as faculdades "altas" do visual e do visionário e os sentidos "baixos" do cheiro e do tato? Gauguin busca elevar esses sentidos baixos - associados, por sua vez, com aquilo que é primário e "primitivo", com o outro gênero e a outra raça. Na verdade, ele busca sublimá-los em "fragrância" estética. Perfume sinestésico é, afinal, o próprio significado do termo noa noa.

Esse movimento sublimatório aponta o papel ideológico do olfato no primitivismo - o que justifica um pequeno adendo. Em 
Noa Noa e em outros escritos, Gauguin se refere a essa fusão sinestésica entre memória e percepção em termos de misturas de sons e também de cheiros. Por exemplo: "Eu sonho com harmonias violentas nos odores naturais que me intoxicam"27. Ambas essas alusões estão em sintonia com conviç̧ões de sua época: da música enquanto modelo ideal das artes, do olfato enquanto sentido das afinidades. Segundo o historiador Alain Corbin, essa definição do olfato é parte de um código burguês de sensibilidade que só se torna dominante no século XIX. Foi somente naquele momento que o odor do lixo passou a ser considerado uma ameaça à ordem social - uma ameaça associada primeiramente ao camponês, então ao proletariado e, finalmente, ao "primitivo"28. Tal refinamento do olfato indica um processo de complexificação da sociedade: em seus "Manuscritos econômicos e filosóficos” (1844), Marx, inclusive, relaciona a diferenciação dos sentidos diretamente às divisões de trabalho, propriedade e classe. Ora tidos como sensíveis aos odores (isto é, como naturais, a exemplo do nativo em Noa Noa), ora como insensíveis (isto é, não civilizados), nem o camponês, nem o proletário e nem o "primitivo" poderiam escapar a essa associação "natural". Tanto em Noa Noa quanto em outros escritos, não obstante, Gauguin busca revalorizar essa afinidade, compreendendo o "primitivo" não como 
figura do mal-cheiro, mas do noa noa. A um só tempo primária e refinada, essa fragrância é mobilizada visando perturbar ambas a ordem sensória européia e a hierarquia social nela implícita. Nesse ponto, Gauguin pode simplesmente desenvolver a fantasia francesa do Taiti como um lugar de amor livre, troca de presentes e daí em diante $^{29}$. Mas ele também se refere ao desejo historicamente situado de que o olfato, esse sentido exaurido na Europa, possa rejuvenescê-la e até mesmo "intoxicá-la" para superar - ao menos magicamente - a divisão de trabalho, propriedade e classe. Esse fascínio, é claro, é hoje parte do pacote $\operatorname{Club} \operatorname{Med}^{30} \mathrm{e}$, aliás, sempre foi. A conexão entre a sinestesia e a libertação fantasmática das divisões de trabalho, propriedade e classe é sempre importante para o mito primitivista $^{31}$. Poderiamos estender essa libertação imaginária a uma outra divisão, àquela do sexo? Quanto ao intuito de fazer emergir o olfato, o amorfo e o andrógeno noa noa no texto gauguiniano, não seria ele decorrente de uma cegueira sedutora para além dos limites da visão, de um olhar incisivo e mesmo castrador? ${ }^{32}$

Picasso não compartilhava dos ideias de noa noa de Gauguin de sublimação sinestésica do "primitivo”. Pelo contrário, em sua "cena primitiva", o suposto cheiro do Outro primário lhe 
causa repulsa, e em seu trabalho primitivista o óptico e o háptico permanecem em disputa.

A história de Picasso remonta à sua visita, em 1907, ao museu etnográfico Trocadéro em Paris (hoje o Museu do Homem). Foi ela que o fez reelaborar Les Demoiselles d'Avignon. Em certo sentido, portanto, essa pintura é um mapeamento fantasmático de duas cenas que se retroalimentam em uma colisão telescópica de eventos imagéticos ainda mais próxima daquilo que Freud compreendia por cena primária do que qualquer outro encontro primitivista: uma visita a um bordel e uma visita ao Trocadéro, um encontro sexual e um encontro racial traumáticos para Picasso ${ }^{33}$. Aqui, a fusão entre o "primitivo" e a prostituta parece completa, e os cruzamentos entre desejo e identificação, personificação e objetificação, são ainda mais delirantes.

Todo mundo sempre fala sobre a influência que os Negros tiveram sobre mim. O que eu posso fazer? Todos nós adorávamos fetiches. Van Gogh um dia disse: “Arte japonesa - todos nós tínhamos isso em comum." Para nós, eram os Negros. [Note-se a equivalência entre Negro e fetiche.]

Quando eu fui ao velho Trocadéro, foi repugnante. O mercado de pulgas. O cheiro. Eu estava completamente sozinho. Eu queria ir embora de lá. Mas eu não fui. Eu fiquei. Eu fiquei. Eu entendi que aquilo era muito importante: alguma coisa estava acontecendo comigo, certo? [Note-se 
a linguagem de suspensão: assim como ocorre com a fixação do fetiche, Picasso compreende essa possessão como processo de se tornar primitivo.] As máscaras não eram como quaisquer outras esculturas. De forma alguma. Elas eram coisas mágicas. Mas por que as peças egípcias ou da Caldeia não eram? Nós não tínhamos nos dado conta. Aquelas eram coisas primitivas [isto é, pré-clássicas], não mágicas. As peças Negras eram intercesseurs; desde então eu aprendi esta palavra em francês. Elas eram contra tudo - contra espíritos desconhecidos, ameaçadores. Eu olhava o tempo todo para esses fetiches. Até que entendi: eu também sou contra tudo. Eu também acredito que tudo é desconhecido, que tudo são inimigos! Tudo! Não só pequenos detalhes - mulheres, crianças, bebês, tabaco, jogo -, mas tudo! Eu entendi para o que os Negros usavam suas esculturas... Todos os fetiches eram usados para a mesma cosia. Eles eram armas. Para ajudar as pessoas a evitar a influência dos espíritos novamente, para ajudá-las a tornarem-se independentes. Espíritos, o inconsciente (as pessoas ainda não estavam falando muito sobre isso), a emoção, tudo é a mesma coisa. Eu entendi porque eu era um pintor. Completamente sozinho, naquele museu assustador, com máscaras, bonecas dos peles vermelhas, manequins empoeirados. Les Demoiselles d'Avignon deve ter me ocorrido justamente naquele dia, mas jamais por causa das formas: porque tratava-se da minha primeira pintura de exorcismo. Sim, absolutamente! (PICASSO apud MALRAUX, 1976, pp. 10-11) ${ }^{34}$

Em meio à cortina de fumaça típica de Picasso, existem algumas percepções que não posso mais do que registrar aqui. 
Ainda que esse seja apenas um entre tantos relatos, reparese na leitura dos objetos tribais em termos de valor ritual, não formal. Como antropólogos, de James George Frazer e Freud a Mary Douglas, Picasso percebe no "primitivo" uma identificação estreita entre o sagrado e o profano, entre a potência da desordem e da sujeira. Nesse reino de poluição e tabu, ele situa os objetos como agentes dotados de poder fetichista, até mesmo apotropaico (intercesseurs, escudos, armas), como "espíritos" a serem utilizados para defender-se contra outros "espíritos". Mas é aqui também que Picasso participa da ambivalência imputada aos "primitivos" incluindo não apenas os espíritos, o inconsciente, a emoção, mas também as "mulheres, crianças, [e] bebês -, já que ele quer a um só tempo participar e se distanciar de seus impactos. Em poucas palavras, ele pretende utilizar o "primitivo" para exorcizar o próprio "primitivo", posicionar o desconhecido e o indistinto contra essas mesmas ameaças. De modo mais explícito que em Gauguin, essa é a clássica ambivalência primitivista entre o desejo pela regressão e dessublimação (“alguma coisa estava acontecendo comigo, certo?”), por um lado, e a necessidade de autonomia e sublimação ("ajudálas [as pessoas] a tornarem-se independentes") por outro - uma ambivalência operante não apenas no modernismo primitivista 
masno alto modernismo tout court ${ }^{35}$. Aqui ealhures, essa autonomia é delimitada tanto contra a ameaça dessublimatória do feminino (mulheres, crianças, bebês) quanto contra a escravização fetichista dos negros ${ }^{36}$.

Ainda que Picasso opte pelo "exorcismo", ele sustenta suas ambivalências mais integralmente do que Gauguin. Por um lado, ele associa os objetos tribais com a poeira e o odor, reagindo contra esse reino de sujeira e merda. Esse reino de "matéria fora do lugar" o ameaça por sua indistinção, e é precisamente a associação entre a indistinção, o feminino e o negro o que o torna regressivo para Picasso ${ }^{37}$. Por outro lado, esse reino o atrai, pois a regressão promete também libertação subjetiva e inovação artística. Em outras palavras, Picasso percebe que essa esfera regressiva pode ser utilizada de modo transgressivo - em direção a uma ruptura vanguardista não apenas com a tradição do nu (Les Demoiselles d'Avignon dessublima o nu de modo mais radical do que a Olympia ou Espírito dos Mortos Assistindo), mas também no que concerne à compreensão do signo visual (Picasso, sem dúvida, inaugura essa ruptura com a complexidade espacial de Les Demoiselles, embora ele a ratifique só depois, com a multiplicidade semiótica das colagens e construções desenvolvidas mais tarde, em uma reação $a$ 
posteriori em relação aos seus primeiros encontros “primitivos") $3^{3}$. De todo modo, o que mais importa aqui é que esse movimento de transgressão vanguardista é garantido por um impulso em direção à regressão psíquica - concebida como anticivilizatória (isto é, como “primitiva”) por Picasso, assim como por Freud antes dele.

Em "O mal-estar na civilização" (1930), Freud correlaciona os desenvolvimentos da civilização e do indivíduo. Nesse texto, a formação reativa é considerada quase mais importante do que a sublimação e a renúncia, especialmente a formação reativa contra o erotismo anal. Aliás, esse é o ponto crucial de sua mais célebre cena primária da civilização: quando o "homem" se ergueu ereto pela primeira vez, expondo seus genitais, descobriu a vergonha e, em meio a esses outros atos heróicos, elevou a faculdade visual sobre a olfativa. Segundo Freud, a formação reativa contra a sujeira e o transtorno anal é tão fundamental para a arte quanto para a civilização. Mexer com essas coisas, então, é literalmente se meter com elas. "O erotismo anal", Freud escreverá em outro texto, "encontra uma aplicação narcisista na produção da obstinação" (FREUD, [1917] 2010, p. 258). Assim também ocorre coma obstinação vanguardista, eu sustentaria. Quantos não foram os gestos vanguardistas a invocar a sujeira ou a merda? (Considere-se todos 
os ataques à ordem formal promovidos pelo dadá e o surrealismo, pela neovanguarda dos anos 1950 e pela arte pós-minimalista dos anos 1960, e, mais uma vez, por obras contemporâneas que se voltam a corpos violados e limites transgredidos). Aqui, entretanto, Picasso demarca um limite, pois a dessublimação também tem suas limitações enquanto estratégia. E mais: ele se esquiva dos limites; ele detesta a sujeira, o cheiro, o erotismo. Mesmo quando ele é arrebatado para o interior de sua cena "primitiva", ele reage contra ela, sentindo repulsa pelo primário psicossexual, desesperado por distinção, sedento por domínio, ao ponto de também projetar agressividade, e até sadismo, sobre o "primitivo".

Mas como essa ambivalência foi registrada pictoricamente? Como no caso de Gauguin, não podemos remetê-la estritamente à irresolução artística de Les Demoiselles, uma vez que, conforme demonstrou Leo Steinberg, todas as mudanças abruptas da pintura foram propositais. Mais uma vez, então, como podemos sondar articulações entre a psique e o trabalho artístico? Evidentemente, o encontro duplo reelaborado na pintura - com os objetos tribais e as prostitutas de Barcelona - foi traumático para o supersticioso e sifilofóbico Picasso. Les Demoiselles, no entanto, não resolve essa ameaça de castração e de morte por meio de seus Outros fantasmáticos. Ela é, na verdade, uma (re)encenação dessa 
ansiedade - sendo a própria (re)encenação, como tal, crucial para o impacto da obra, pelo menos sobre o espectador "picassóide”, um sujeito masculino como Picasso. (Obviamente, diferentes sujeitos verão essa pintura de modos distintos - uma consideração que qualquer interpretação deve levar em conta.).

Como, então, essa (re)encenação é concretizada? Como se sabe, havia dois caminhos sinalizados em Les Demoiselles, cuja versão final foi alcançada após a visita ao Trocadéro - no momento em que Picasso "primitivizava" o rosto de três das figuras na pintura, isto é, as duas da direita e aquela mais à esquerda. Entretanto, antes desse estágio, em dois estudos importantes, ele transforma não apenas o conteúdo de Les Demoisellles, mas a orientação das figuras em relação ao espectador. Como descreve William Rubin, Picasso redefiniu a pintura, partindo de um modo narrativo - antes, talvez, uma alegoria da sífilis, com um marinheiro sentado no centro do quadro e um estudante de medicina na lateral esquerda (como no estudo de Basel [figura 11]) - em direção a um registro icônico, no qual esses substitutos para o espectador picassóide são eliminados ${ }^{40}$. $\mathrm{O}$ efeito dessa elisão é conferir às Demoiselles um olhar direto. A pintura converte-se em um encontro com o espectador. De fato, o olhar das prostitutas para o sujeito picassóide é como o olhar dos 
lobos para o Homem dos lobos. O olhar do observador é duplicado, mantendo-se também suspenso entre desejo e identificação, atração e ansiedade ${ }^{41}$.

Em “The Philosophical Brothel”, Steinberg (1972, pp. 7-74) traça uma leitura fenomenológica da pintura, que pode ser reconsiderada em termos psicanalíticos. Por exemplo, a partir da noção de que Les Demoiselles estabelece "uma relação recíproca de assimilação [engulfment] e penetração" (Ibidem, p. 64) que "sugere uma iniciação total, como se entrássemos em uma cama bagunçada" (Ibidem, p. 33). O que essa reciprocidade evoca senão a estrutura da cena primária, também ela emoldurada como um quadro e fixada por um olhar silencioso, que "traga e expele, para dentro e para fora, [impregnado de] algo similar a uma energia sexual"? Assim como na cena, há, na pintura, um intenso cruzamento não apenas entre o óptico e o háptico, mas também entre o ativo e o passivo. No limite, o espectador pode se sentir quase tão "estilhaçado" quanto o Homem dos lobos, sendo toda a hierarquia "civilizada" entre os sentidos e os sexos perturbada.

E, no entanto, como com Gauguin, é necessário questionar de Picasso a qual fim se presta tal (re)encenação. Não se trata, em parte, de uma forma de gerir a ansiedade masculinista de uma cena 
como essa? Picasso não admite, afinal, que as prostitutas-primitivas são como "armas" apotropaicas contra a própria alteridade sexualracial que elas supostamente representam? O fato de Picasso proporcionar tal "exorcismo" contribui muito para explicar o privilégio cultural concedido tanto à pintura quanto ao pintor por sua performance. E não obstante, será que essa função paliativa de Les Demoiselles cancela seus efeitos disruptivos?

Eu mesmo fiquei aliviado em descobrir que não existe uma história de Kirchner semelhante àquelas de Gauguin e Picasso. O primitivismo de Die Brücke é, em grande medida, um romance de ateliê [studio affair]; os expressionistas que de fato viajaram ao Pacífico, como Max Pechstein e Emil Nolde, o fizeram sobretudo como uma emulação boêmia de Gauguin. Mas, afinal, se o primitivismo é sempre de segundo grau, não seria esse atraso relativo o que impediria o fervoroso engajamento de Kirchner em seu teatro visual, especialmente de 1909 a 1911. 
entretenimento racialista - assim como o mapeamento do "primitivo" sobre a prostituta - é algo típico do Die Brücke. Evidentemente, Kirchner era obcecado pela figura da prostituta; e o fato de que essa figura, em sua pintura, fosse amiúde disposta em ambientes urbanos dificilmente reduzia, para ele, sua "natureza primitiva" [primitivity]. Kirchner, aliás, enfatizou o signo anal da sexualidade "primitiva" ainda mais explicitamente do que qualquer outro modernista. Seus ateliês eram repletos de imagens correlatas [de analidade] (por exemplo, figuras sentadas, agachadas e deitadas, vistas de trás, cercadas de imagens de animais e esculturas primitivistas); com amigos e modelos, ele encenava poses semelhantes (em particular, com duas crianças precoces chamadas Franzi e Marzella e com dois dançarinos de jazz conhecidos apenas como Sam e Milly [figura 13]). Mas onde está sua cena "primitiva”?

Em certo sentido, ela está inscrita nas diferentes imagens e performances de seu ateliê. Há, todavia, uma imagem capaz de tornar sua fixação mais nítida para nós: um pequeno desenho em um cartão-postal enviado para Erich Heckel (figura 14). Em suas visitas ao museu etnográfico, Kirchner ficou fascinado pelos frisos de viga das casas de homens jovens [bachelor house] de Palau, uma colônia alemã na Micronésia ocidental. Entretanto, de todas 
as figuras disponíveis, ele se fixou em apenas uma: uma imagem representando um mito local de coito a tergo, envolvendo um homem com um pênis gigante. Kirchner, aqui, deparou-se com seu signo de sexualidade "primitiva": na sua versão do cartão-postal, o pênis chega a ser ainda maior e as nádegas da mulher ainda mais graúdas, como se estivessem sob o efeito de sua fantasia anal-erótica. Kirchner repete essa imagem obsessivamente em sua arte e em seu ateliê. Ela está lá, acima de sua figura primitivista mais famosa, Menina sob um guarda-chuva japonês (c. 1909), pintada por volta da mesma época (figura 15). A figura que aparece sob um guarda-chuva japonês - emblema de ateliê de todos os exotismos e primitivismos sobre os quais me detive - também surge, aqui, sob o signo do erotismo anal.

Como outros primitivistas, Kirchner com frequência elide a figura fálica da imagem do cartão-postal. Talvez essa figura fantasmática de uma sexualidade excessiva gerasse ansiedade demais para eles. Ou, talvez, essa figura precisasse ser suprimida para que esses sujeitos brancos pudessem, por procuração, tomar o seu lugar. Acredito que ambos os movimentos operam no primitivismo modernista, pois é apenas então que esse sujeito branco pode assumir a sexualidade putativa do Outro sem ansiedade; apenas então que ele consegue lidar com a inveja do pênis em sua versão racialista. 


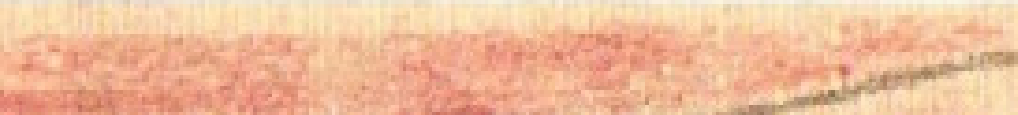

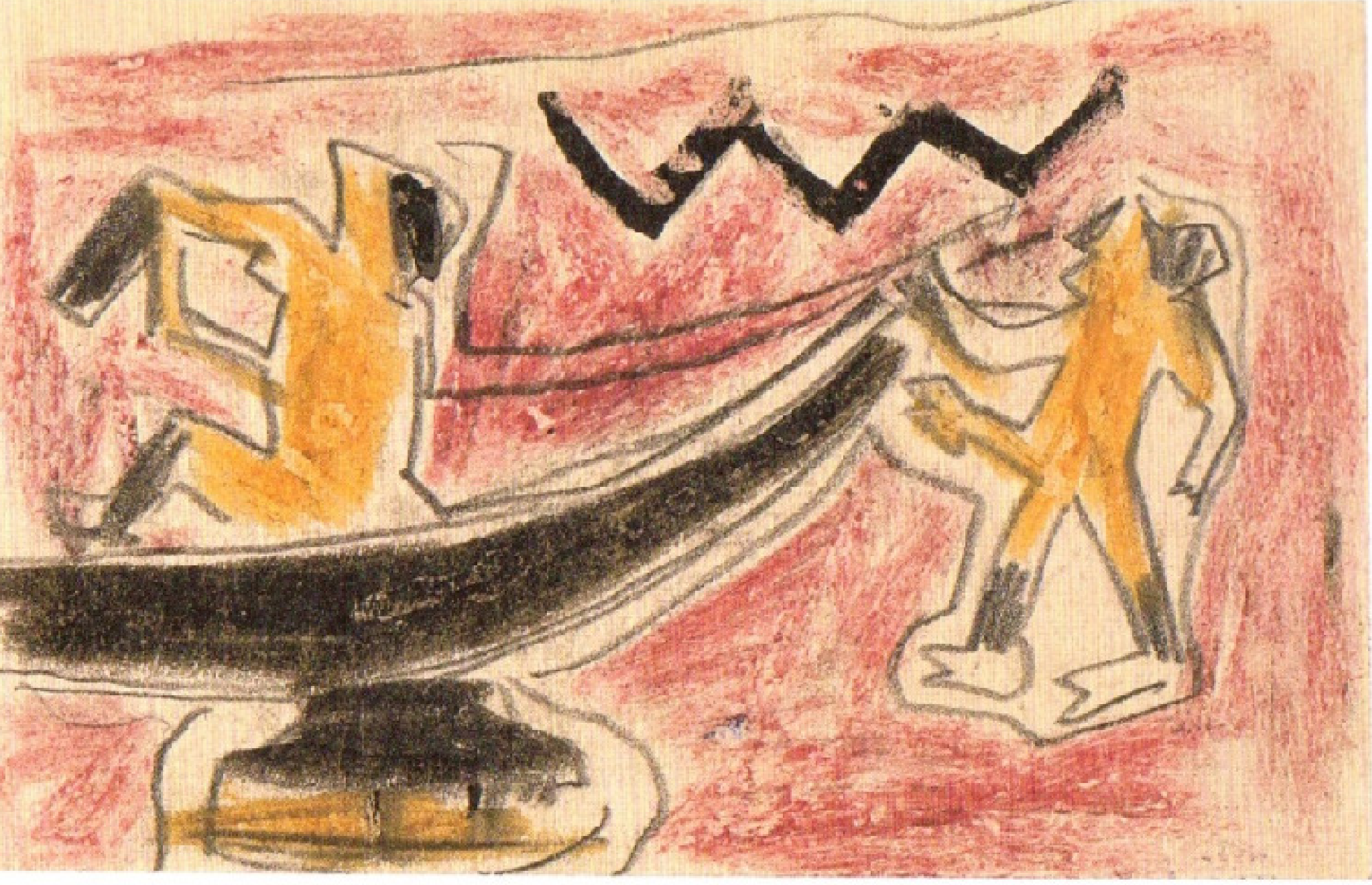


FIGURA 9. (NA PÁG. ANTERIOR)

Ernst Ludwig Kirchner, detalhe de desenho em cartão-postal, 1910. Altonaer Museum für Kunst und Kulturgeschichte, Hamburg.

\section{FIGURA 10.}

Ernst Ludwig Kirchner, Menina sob um guardachuva japonês, c. 1909. Óleo sobre tela, $92 \times 80 \mathrm{~cm}$. Kunstsammlung Nordrhein, Düsseldorf.

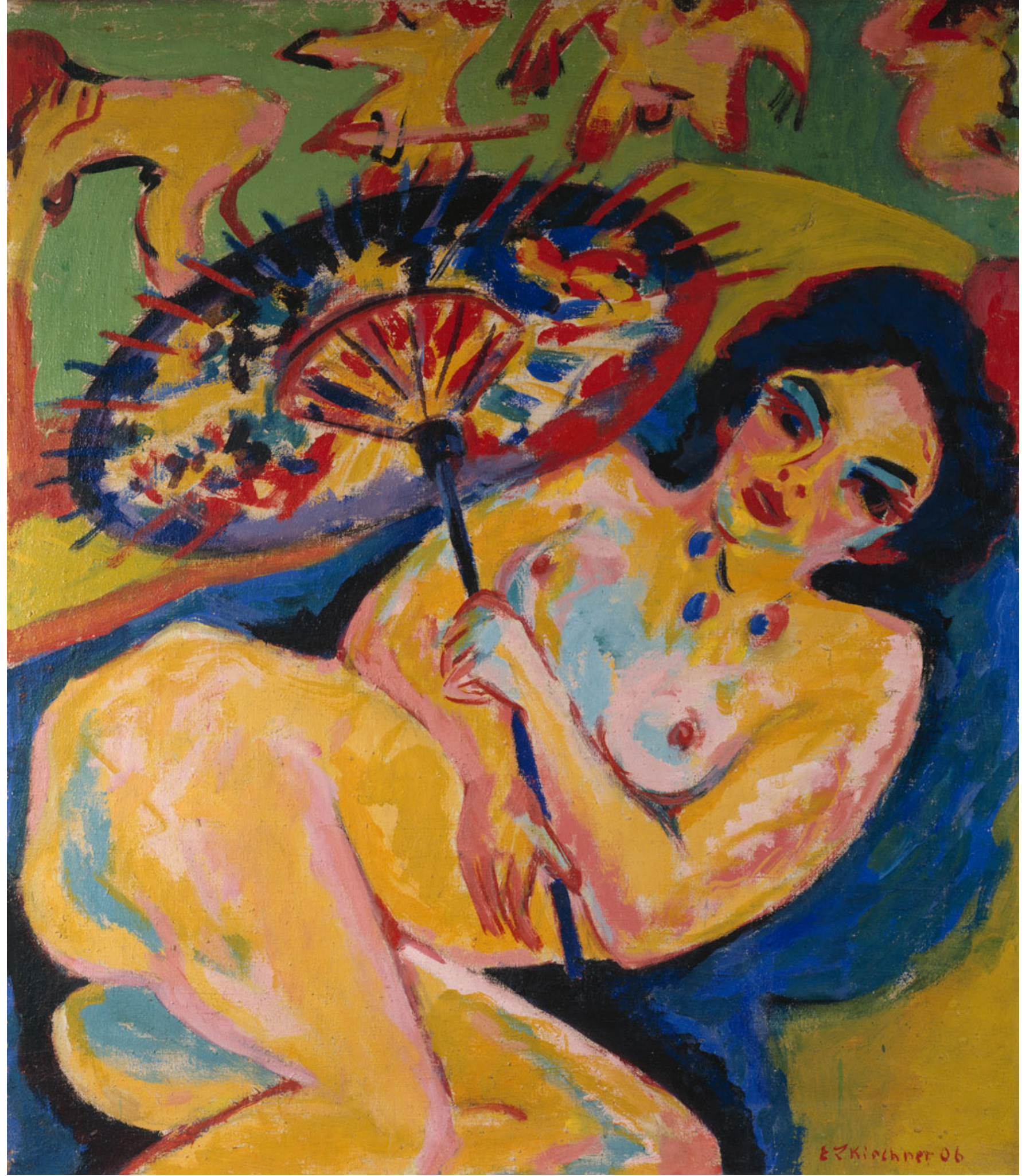

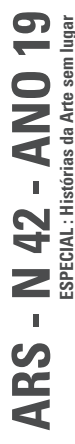

1631 
Devo esclarecer prontamente essa declaração. O que eu quero dizer é que a ambivalência sexual desses primitivistas talvez seja composta por uma ambivalência racialista, isto é, pela presunção de superioridade cultural em tensão com a suspeita de inferioridade sexual. Evidentemente, a destreza sexual projetada no Outro negro é raramente reconhecida como tal. Ela é, antes, inscrita em termos substitutos, tais como "a força ritualística" do artista tribal africano ou do músico de jazz americano. Mas a projeção, ainda assim, segue operante, e revela um conflito peculiar na autoimagem desses sujeitos brancos masculinos. Será possível que Freud estivesse errado sobre a inveja do pênis? Será que, ao invés de estar restrita a garotinhas (se é que ela sequer estava lá), ela não estaria mais ativa em pequenos homens, isto é, em homens que suspeitavam ser pequenos - o que significa dizer que ela estava atrelada a todos nós, garotinhos? 43

Acredito que essa ambivalência racial (ou inveja do pênis) é ainda mais complicada por uma ambivalência patriarcal (ou ardil fálico), o que também está apenas implícito em Freud. Em seu cenário, o filho projetado como heterossexual é requisitado a se identificar com opai, embora não em um aspecto crucial: oprivilégio sexual relativo à mãe. O signo dessa hierarquia de privilégio sexual 
é a suposição de que o pênis paterno é grande - uma aposta que, conforme as feministas há muito tempo apontaram, o patriarcado mantém em suspenso com essa presunção fálica, através desse truque que faz com que o pênis sorrateiramente assuma o papel do falo ${ }^{44}$. Uma aposta, além disso, que o patriarcado mantém em suspenso com a persistência do desejo homossexual no homem heterossexual, como recentemente argumentaram os críticos da masculinidade. Pois apenas essa combinação entre identificação e desejo pode fixar o homem psiquicamente na hierarquia patriarcal. Como argumentei em relação ao Homem dos lobos, pode haver na relação primitivista com o Outro "racial” uma confusão similar entre identificação e desejo, uma mistura semelhante das relações edípicas negativas e positivas. Quando agravada por uma versão racialista da inveja do pênis, essa confusão edípica pode impulsionar a ambivalência do primitivista, atrelando-o a uma hierarquia sexual-racial conflituosa: por um lado, há um paternalismo patente no que se refere ao Outro (por exemplo, o homem negro, socialmente, como um serviçal), por outro lado, há uma reverência secreta em relação ao Outro (o homem negro como mestre sexual). Essa hierarquia imaginária também pode sugerir o motivo pelo qual o homem "primitivo" jamais pode ser “feminilizado", à maneira das 
representações de homens Orientalistas e Japonistas. Uma vez que a ansiedade sexual-racial não pode ser acalmada desse modo, a figura do homem negro deve ser elidida, e sua posição, evacuada - mas, mais uma vez, apenas para que o homem branco se coloque em seu lugar. Nesse sentido, a identificação primitivista acoplada ${ }^{45}$ ao desejo pelo homem negro implica, também, o seu apagamento, e esse apagamento, por sua vez, é crucial para a fantasia primitivista ${ }^{46}$.

Ainda que parcialmente, Gauguin foi capaz de sublimar a sua própria ambivalência à sua maneira sinestésica, e Picasso conseguiu trabalhar formalmente a sua, de modo a manter a regressão psíquica à altura da transgressão artística. Kirchner também tentou dar conta de sua ambivalência, mas seu expressionismo era demasiado dessublimatório e não lhe permitia mediá-la ou administrá-la adequadamente. Talvez sua masculinidade estivesse sob maior pressão do que a dos outros dois. Ao ser convocado para a Primeira Guerra Mundial, Kirchner teve um surto nervoso; paralizado histericamente durante algum tempo, ele passou pela experiência de um severo rompimento na imagem de seu corpo (Autorretrato como soldado [1915, figura 16] é uma auto-mutilação simbólica das mais violentas). Até mesmo depois, no exílio na Suiça, Kirchner teve de sobreviver suportando o escudo fascista da 
subjetividade masculina, imposto justamente como uma reação contra tais perturbações do corpo e do ego. A analogia estética desse escudo é aparente no paradigma nazista do nu masculino, um corpo fálico despido de todas as sexualidades “primitivas”. Essa estética, à semelhança do regime político que lhe corresponde, não tolerava qualquer tropismo dos "primitivos" e, como se sabe, estigmatizava todas as figuras associados ao "primitivo" como degeneradas - judeus, comunistas, ciganos, homossexuais, prostitutas, os loucos, e muitos outros. Estigmatizado de forma semelhante, Kirchner cometeu suicídio. E apesar de todas as suas intenções e propósitos, o primitivismo modernista encontrou sua catástrofe literal - sua culminação e seu inverso - nesse outro (e tão diferente) primitivismo dos nazistas.

De muitas perspectivas, a crise primitivista da masculinidade branca heterossexual que eu (re)construí aqui talvez soe como uma atitude indulgente, que tão somente explora e usurpa posições-subjetivas alheias (o nativo, em Gauguin, e Sam, em Kirchner, sem contar contar todas as mulheres-adereço em outras cenas "primitivas”). Em síntese, a ambivalência dessa masculinidade talvez constitua apenas mais um privilégio. Pode ser também, então, que 
essa ambivalência não perturbe tanto a masculinidade dominante quanto eu sugiro. Outra vez, de acordo com Freud, a heterossexualidade masculina envolve uma relação edípica negativa - um instante de desejo pelo pai-, e essa homossexualidade subordinada talvez seja estrutural para o homem heterossexual e necessária para sua inscrição patriarcal. Resumindo, talvez essa ambivalência não sustente a mobilidade de posição subversiva que por vezes propus. Eu resolvi tomar esses riscos por uma razão. Em sintonia com muitos outros críticos e artistas hoje, parece-me imperativo examinar de que maneiras as oposições explícitas de gênero (masculino e feminino) e cor (branco e negro) se sobrepõem e se reconfirmam, de um modo que torna as complexas diferenças entre posições sexuais e origens étnicas tão difíceis de se refletir sobre. Parece-me imperativo, também, examinar de que maneiras as diferenças sexuais são ocultadas pela racialização da sexualidade e de que maneiras as diferenças étnicas são obscurecidas pelas sexualizações de raça. Esses são, sem dúvida, problemas contemporâneos, mas formados historicamente, e apenas uma investigação que mantenha no horizonte ambas essas dimensões será capaz de esclarecê-los. 
1. Sobre essa conexão, cf. DOANE (1991). Esse texto, o melhor que eu conheço sobre Fanon e psicanálise, cruza-se, em certos pontos, com o meu.

2. Essa noção evolucionista da "reminiscência" - de cujas associações primitivistas Freud não se furtou (como, por exemplo, na definição da fase oral como canibalista) - conturbou quase tanto a psicanálise quanto a antropologia.

3. No discurso racialista, judeus são frequentemente considerados demasiadamente civilizados, isto é, desenraizados, decadentes, degenerados e, deste modo, "primitivos" outra vez. Sobre esse discurso de norma e desvio, cf. GILMAN (1985).

4. Freud afirma categoricamente que mulheres são "pouco capazes" de sublimação e inclusive "hostis" à civilização, cf. FREUD ([1930] 2010). A justificativa para essa propensão é desenvolvida em textos como "Algumas consequências psíquicas da distinção anatômica entre os sexos" (1925), nos quais o superego relativamente frágil da menina é atribuído à suposta irresolução de seu complexo de Édipo.

5. Sobre essa imagem, cf. BRANGLINGER, (1985, pp. 166-203), e sobre seu uso em Freud, cf. DOANE (1991). A África foi rotulada como "negra" para justificar o imperialismo vitoriano (como Brantlinger demonstra), mas, antes, ainda, para justificar o tráfico de escravos. Essa exigência não foi tão importante no caso da Oceania, a outra alteridade "primitiva", que permaneceu como um lugar iluminado.

6. Sobre esse "idílio de consumo irrestrito, oral e genital", cf. WHITE (1994, p. 209). Sobre seu uso na figuração feminina do Novo Mundo, cf. MONTROSE (1991, pp. 1-41). Entre outras práticas atribuídas ao "primitivo", White inclui a nudez, a ausência de leis e a propriedade comunal. Contra todas as evidências, Gauguin insiste nesses estereótipos quando projeta o Taiti como um lugar livre do dinheiro, e as Ilhas Marquesas, como um lar de canibais. Aliás, é lá que ele procede conforme a equação primitivista de distância no espaço e no tempo. É esse mapeamento do tempo-espaço que o permite conceber sua viagem para 
o exterior como uma viagem de retorno - seja aos primórdios da espécie, do sujeito ou da civilização. Assim, Gauguin (1985a, p. 15) escreve: "É preciso voltar à fonte original, a infância da humanidade". E: "Algumas vezes, eu voltei para longe, tão ou mais longe do que os cavalos do Parthenon. Tão longe quanto ao Dada da minha infância, o bom e velho cavalo de balanço".

7. Quando a figuração do gênero [gendering] do selvagem passa do masculino ao feminino? Ela acompanha a grande virada na história do nu? Ou ela reflete uma reconfiguração na representação da figura do selvagem, das balizas sociais limites às balizas de fantasias sexuais?

8. 0 autor parece utilizar a palavra subject, aqui, no duplo sentido de "sujeito" e "assunto", ou conjunto de assuntos que retroalimentam uma identidade subjetiva. Optamos por traduzir a palavra por sujeito uma vez que, em seguida, ela relaciona-se com a noção de "encontro subjetivo". [N.T.]

9. Eu mobilizei o conceito de fantasia primária em relação às histórias de origem surrealistas em FOSTER (1991, pp. 19-54). Ver também FOSTER (1993).

10. Nesse aspecto, 0 "primitivo" é duplicado pela máquina como o principal objeto fantasma do alto modernismo. Através deles, esse modernismo simultaneamente reconhece e rejeita suas pré-condições primárias: o intensificado relativismo cultural do alto imperialismo e a intensificada instrumentalidade tecnológica do alto capitalismo. É por isso que esses dois fetiches são figurados com tanta frequência em suas próprias fábulas de identidade.

\section{Cf. GARDNER (1971, p. 170). Cf. FREUD ( [1918] 2010, pp. 13-160).}

12. Em diversos momentos do texto, Hal Foster refere-se à noção psicanalítica de Nachträglichkeit através da expressão em inglês "deferred action". Em consonância com outras traduções brasileiras de textos do autor e com a tradução consultada dos textos de Freud (FOSTER, 2017, pp. 44-49; FREUD, 2010), optamos por traduzir essa expressão como "efeito a posteriori". Cumpre notar, de todo modo, que no meio específico da psicanálise (lacaniana, em especial), o conceito de Nachträglichkeit é frequentemente traduzido como "só-depois", evocando o termo em francês "après-coup", empregado por LAPLANCHE; 
13. É possível separar o conceito de regressão de sua presunção primitivista, assim como fizemos com a noção de fases? Caso contrário, como essas suposições afetam a crítica cultural que se utiliza desse conceito (por exemplo, as respectivas críticas do modernismo e cultura de massa como regressivos, por Lukács e Adorno)?

14. Deve-se destacar que a psicanálise freudiana vê a ambilavência como particularmente ativa no estágio anal - na tensão entre retensão e expulsão de fezes; na ambiguidade entre o excremento como um produto amado, que deve ser conservado, e como uma merda execrada, que deve ser destruída; e assim por diante.

15. Esse risco não é levado em conta na literatura inicial sobre erotismo anal: em diferentes momentos, Freud, Sandor Ferenzci, Karl Abraham e Ernest Jones, todos postulam a arte como "uma sublimação do impulso primitivo de manchar". Cf. JONES (1961).

16. Gauguin levou consigo uma fotografia da pintura para o Taiti como uma espécie de talismã.

17. Cf. GILMAN (1985, pp. 204-242). A melhor inversão de valores quanto a esse traço de sexualidade é a música "Baby Got Back" do rapper de Seattle Sir Mix-a-Lot.

18. BAUDELAIRE ([1863] 2016, p. 878). De fato, as esculturas africanas que serviram de inspiração aos artistas modernistas frequentemente manifestam uma analidade patente. Mas essa analidade foi equivocadamente interpretada pelos artistas, especialmente os expressionistas, que assumiam que essas deformações fossem psicossexualmente expressivas - que elas fossem, por certo, expressionistas.

19. Carol Duncan deu início a essa crítica em "Virility and Domination in Early TwentiethCentury Vanguard Painting", cuja importância é evidente. Cf. DUNCAN (1973, pp. 30-39). Eu gostaria apenas de tornar mais complexa sua compreensão do domínio masculinista, daí a minha ênfase na ambivalência do encontro primitivista, que não é meramente a afirmação de tal domínio. Nesse sentido, eu me situo entre duas reflexões recentes sobre Gauguin: SOLOMON-GODEAU (1989, pp. 118-129, 161) e BR00KS (1990, pp. 51-90). Meu texto também 
é influenciado por uma palestra de Griselda Pollock em 1989 a respeito da obsessão de artistas franceses do século XIX, de Millet a van Gogh, por imagens de mulheres camponesas e proletárias trabalhando curvadas, amiúde dispostas em poses quase bestiais. Em representações primitivistas, evidentemente, esse gesto de submissão pictórica de classegênero está relacionado à submissão de raça-gênero, em conformidade com a instabilidade (observada acima) entre "o primitivo", o camponês e o proletário no imaginário burguês da época.

20. Sobre isso, cf. RICHON (1985, pp.34-41). Sobre arte orientalista do séculoXIX, cf. NOCHLIN (1983, pp. 118-131, 187-191), e sobre a cultura orientalista do século XIX, cf. WOLLEN (1987, pp. 5-33). A demonstração direta de poder sexual-político no Outro masculino pode produzir ansiedade no observador ocidental: uma identificação com esse poder demanda que 0 representante exótico seja subjugado (como na história de Sardanapalus), de-generizado [degendered] (como acontece frequentemente com figuras orientalistas e japonistas), ou ausente (como acontece com o homem negro no primitivismo modernista - confira mais sobre isso a seguir).

21. Poderia essa homofilia orientalista, que se reverte em homofobia, subscrever a paranóia política que há muito tempo permeia as relações do ocidente com esse "oriente"?

22. 0 discurso japonista frequentemente apresenta a cultura japonesa como um terceiro termo contraditório, ao mesmo tempo "primitivo" e "civilizado", infantil e decadente.

23. "Civilização que o faz sofrer", Gauguin (1996, p. 79) escreve a August Strindberg em 5 de fevereiro de 1895. Mesmo invertido, esse discurso retém seu aspecto imperialista, por exemplo, nas imagens da Europa exaurida, em necessidade de uma renovação colonial. (Esse também é o momento dos parques nacionais, dos safáris africanos, dos escoteiros, e daí em diante).

24. Em "Gauguin's Tahitian Body", Brooks (1990) argumenta que Gauguin buscou reinventar uma Eva pura e selvagem para substituir as Vênus corrompidas exibidas nos Salões. Essa tentativa estaria também relacionada à necessidade de reunificar as correntes afetivas e sexuais? 
25. É claro que essas localidades obedecem a especificidades nacionais: Gauguin viaja para possessões francesas no Caribe e no Pacífico sul; Kirchner se concentra na arte de Palau, uma colônia alemã na Micronésia e Picasso está mais interessado em objetos que vieram dos domínios franceses da África e da Oceania para Paris.

26. A história da publicação de Noa Noa é complicada. Houve três versões iniciais: um esboço feito em Paris em 1893 por Gauguin, uma elaboração em 1897 por Charles Morice e uma edição em 1901 que incluía a colaboração de ambos. A tradução apresentada aqui [por Hal Foster] é baseada na primeira dessas versões.

N.T.: Optamos por traduzir a própria tradução de Hal Foster, uma vez que as traduções de Noa Noa disponibilizadas em português diferenciavam-se substancialmente daquela utilizada no artigo original. Mediante cotejo, utilizamos como base a versão brasileira GAUGUIN (1977).

27. Aqui Gauguin é citado por Nicholas Wadley nas notas de sua tradução de Noa Noa (GAUGUIN, 1985b, p. 146).

28. Cf. CORBIN (1986). “A obsessão pelo odor dos pobres perdeu o vigor durante a segunda metade do século [...] Doravante seria o odor da raça que constituiria uma ameaça" (Ibidem, p.157).

29. Brooks, em “Gauguin's Tahitian Body", é particularmente hábil ao lidar com os caprichos históricos dessa fantasia, tão inglesa quanto francesa. Em "Totem e Tabu", Freud sugere que “o contrário de tabu, na Polinésia, é noa” (FREUD, [1913] 2012, p. 27).

30. Club Méditerranée, ou Club Med, é uma rede de hotelaria francesa que presta serviços de luxo e conta com uma grande rede de resorts em outros países. A ideia de que a viagem de Gauguin ao Taiti seria parte do pacote de uma "visão paradisíaca Club Med" foi desenvolvida por BROOKS (1990, p. 53). [N.T.]

31. Sobre sua persistência em Lévi-Strauss, ver LÉVI-STRAUSS (1996, pp. 34-44).

32. Em Gauguin, há um jogo complexo entre a visão penetrante e o corpo opaco. (Cf. a cena em Noa Noa que concerne ao mistério de Tehamana e ao advento do Espírito dos 
mortos assistindo, assim como os comentários relevantes em Brooks.) Esse tropo da (im)penetrabilidade é também acentuado em outros textos primitivistas (por exemplo, em Coração das trevas), ou onde quer que haja uma associação por deslizamento entre "continentes negros" sexuais e imperiais.

33. Encontros como esse, em vitrines etnográficas, ocorrem em diversas narrativas de fundação da arte moderna. Wilhelm Worringer, por exemplo, inicia Abstraction and Empathy (WORRINGER, 1953) com uma cena desse tipo, também situada no Trocadéro.

34. Note-se que Picasso contou sua história para Malraux pela primeira vez 30 anos depois do evento, de modo que houve bastante tempo para revisões a posteriori [nachträglich]. Além disso, a história foi contada no contexto do surrealismo, o que com certeza preparou sua apresentação como traumática.

35. Será uma coincidência que os artistas que de algum modo suspendem essa tensão entre regressão e autonomia são os mais privilegiados no alto modernismo - artistas como Picasso, Jackson Pollock e Frank Stella?

36. Em Playing in the Dark: Whiteness and the Literary Imagination, Toni Morrisson (1992) expõe esse tropo "africanista" - a escravização dos negros como necessária para a articulação da liberdade branca - como um aspecto central para a imaginação literária americana.

37. Em White Racism: A Psychohistory, Joel Kovel (1984) relaciona associações racialistas entre negritude e sujeira à ambivalência anal: “a sujeira é, em uma raiz simbólica, tudo aquilo que é capaz de passar para fora do corpo, e que, portanto, não deveria passar de volta para dentro do corpo, nem mesmo tocá-lo" (Ibidem, p. 84). Essa formulação se aproxima do abjeto de Kristeva, o qual, sem ser nem sujeito nem objeto, "repousa lá, bem próximo, [ainda que] não possa ser assimilado" (cf. KRISTEVA, 1982, p. 1). No Trocadéro, Picasso está, de fato, no abjeto, em um "vortex de intimações e repulsão [que] situa aquele que está atormentado [pelo abjeto] atrás de si mesmo, literalmente" (Ibidem).

38. Para considerações importantes a respeito do rompimento alto-modernista como fundamentalmente semiótico, cf. BOIS (1987, pp. 33-68) e KRAUSS (1992, pp. 261-286). 
Incitado por Benjamin Buchloh, eu diria que esses dois episódios primitivistas primários de Picasso - c.1907 e c.1912 - não são tão discretos quanto parecem, mas são, na verdade, estruturados em uma relação de efeito a posteriori.

39. Em outra nota de rodapé de "O mal-estar na civilização", Freud apresenta uma cena não menos fantástica que também envolve formação reativa - nesse caso, contra o erotismo uretral. Nesse outro momento primário da civilização, o "homem" renuncia seu desejo "homossexual" de mijar no fogo para conservá-lo como ferramenta. Aqui, é como se a civilização começasse, para Freud, a partir de uma formação reativa contra a homossexualidade. (Uma versão dessa cena também aparece no filme $A$ Guerra do fogo, de 1981, no qual o primeiro que considernva o fogo é também o primeiro a praticar a posição missionária de sexo heterrossexual!).

Por mais que fosse hostil em relação ao modernismo, Freud compartilhava de sua obsessão por mitos de origem, que também tendiam a aparecer em seus textos referentes ao "primitivo" (dentre os quais o mais significativo, psicanaliticamente, é a história do assassinato do pai primário em "Totem e Tabu").

40. Cf. RUBIN (1983, pp. 615-649).

41. Inicialmente, eu supunha que essa comparação perversa, em história da arte, fosse minha invenção, mas outros a empregaram antes de mim. Cf. BOIS (1985, pp. 178-189); WOLLHEIM (1987, pp. 287-295). Nenhuma dessas críticas a tensiona como eu o faço aqui.

42. Essa carta é citada em LLOYD (1991), na melhor discussão sobre primitivismo expressionista até hoje.

43. A suposta visão dos genitais do pai ou do irmão, segundo essa leitura, pode ser mais traumática para o garotinho do que para a garotinha? Mais traumática, talvez, do que a suposta visão dos genitais maternos? Norman Bryson utiliza a noção de inveja do pênis masculina de modo brilhante em uma discussão a respeito da masculinidade desamparada e da hierarquia militar em Géricault. Cf. BRYSON (1993). Meu argumento, aqui, foi formulado graças ao dele.

44. Em "Géricault and 'Masculinity'", Bryson (1993) se refere à história bíblica dos filhos 
de Noé, que cobrem o patriarca, embriagado e nu, para não deixá-lo exposto. No sistema patriarcal, os filhos também relutam em expor o pênis como substituto do falo.

45. No original, Hal Foster fala de "identification cum desire". Nesse caso, o autor faz uso da preposição latina cum, frequentemente empregada, em língua inglesa, entre dois elementos de uma mesma frase para formar um único substantivo cujo sentido é gerado a partir da soma ou da junção dos anteriores, indicando a dupla função de algo. Além disso, o autor parece evocar o sentido coloquial da palavra, que pode significar "gozo", "esperma", "sêmem" ou o próprio ato de ejacular. Optamos por utilizar a palavra português "acoplada" entre ambos os substantivos, embora a ambiguidade patente do original se atenue desse modo. [N.T.]

46. Evidentemente, essa hierarquia racialista da sexualidade é o produto de uma insegurança profunda. Ela persiste, e não apenas em homens brancos (note-se as fantasias de Clarence Thomas com o "Long Dong Silver") ou em homens héteros. A respeito de sua elaboração na pornografia gay, cf. FUNG (1991, pp. 145-160).

47. Em “Armor Fou" (FOSTER, 1991, pp. 66-97), eu examinei esse escudo facista do corpo e da psique. A exposição “Degenerate Art” de 1937, no centro do ataque nazista ao modernismo, concentrou-se ainda mais na arte expressionista do que na arte abstrata, como se o grande anátema devesse ser reservado para a arte (majoritariamente alemã) que representava a maior distorção da imagem do corpo e do ego. Isso é ainda mais irônico tendo em vista que o expressionismo tinha seus simpatizantes nazistas. 


\section{REFERÊNCIAS BIBLIOGRÁFICAS}

BAUDELAIRE, Charles. 0 pintor da vida moderna (1863) / trad. Ivan Junqueira. Poesia e prosa. Rio de Janeiro: Nova Aguilar, 2016.

B0IS, Yve-Alain. La Pensée Sauvage. Art in America, v. 73, abril de 1985, pp. 178-189.

BOIS, Yve-Alain. Kahnweiler's Lesson. Representations, n. 18, primavera de 1987, pp. 33-68.

BRANGLINGER, Patrick. Victorians and Africans: The Genealogy of the Myth of the Dark Continent. Critical Inquiry, v. 12, n.1, outono de 1985, pp. 166-203.

BR00KS, Peter. Gauguin's Tahitian Body. Yale Journal of Criticism 3, primavera de 1990, pp. 51-90.

BRYSON, Norman. Géricault and "Masculinity". In BRYSON, Norman; HOLLY, Michael Ann; MOXEY, Keith (eds.). Visual Culture: Images of Interpretation. Hanover: University Press Of New England, 1993, pp. 228-259.

CORBIN, Alain. The Foul and the Fragrant: Odor and the French Social Imagination / trad. para o inglês Miriam L. Kochan, Roy Porter e Christopher Prendergast. Leamington Spa: Berg, 1986. 
DOANE, Mary Ann. Dark Continents: Epistemologies of Racial and Sexual Difference in Psychoanalysis and the Cinema. In DOANE, Mary Ann. Femmes

Fatales: Feminism, Film, Theory, Psychoanalysis. Nova York: Routledge, 1991.

DUNCAN, Carol. Virility and Domination in Early Twentieth-Century Vanguard Painting. Artforum, v. 12, dezembro de 1973, pp. 30-39.

FANON, Frantz. Pele negra, máscaras brancas (1952) / trad. Sebastião Nascimento. São Paulo: Ubu, 2020. E-book.

FOSTER, Hal. Armor Fou. October, n. 56, primavera de 1991, pp. 66-97.

FOSTER, Hal. Convulsive Identity. October, n. 57, verão de 1991, pp. 19-54.

FOSTER, Hal. Compulsive Beauty. Cambridge: MIT Press, 1993.

FREUD, Sigmund. 0 mal estar na civilização. In FREUD, Sigmund. Obras completas (1930 - 1936), v. 18 - 0 mal estar na civilização e outros textos / trad. Paulo César de Sousa. São Paulo: Companhia das Letras, 2010, pp. 13-122.

FREUD, Sigmund. Sobre transformações dos instintos, em particular no erotismo anal (1917). In FREUD, Sigmund. Obras completas (1917-1920), v. 14 - História de uma neurose infantil ("0 homem dos lobos"), Além do princípio 
do prazer e outros textos / trad. Paulo César de Sousa. São Paulo: Companhia das Letras, 2010, pp. 252-262.

FREUD, Sigmund. História de uma Neurose Infantil. In FREUD, Sigmund. Obras completas (1917-1920), v. 14 - História de uma neurose infantil ("O homem dos lobos"), Além do princípio do prazer e outros textos / trad. Paulo César de Sousa. São Paulo: Companhia das Letras, 2010, pp. 13-160.

FREUD, Sigmund. Totem e tabu: algumas concordâncias entre a vida psíquica dos homens primitivos e dos neuróticos. In FREUD, Sigmund. Obras completas (1912 - 1914), v. 11 - Totem e tabu, Contribuição à história do movimento psicanalítico e outros textos / trad. Paulo César de Souza. São Paulo: Companhia das Letras, 2012, pp. 7-176.

FREUD, Sigmund. Sobre a mais comum depreciação na vida amorosa (1912). In FREUD, Sigmund. Obras completas (1930 - 1936), v. 18 - 0 mal estar na civilização e outros textos/trad. Paulo César de Sousa. São Paulo: Companhia das Letras, 2013. E-book.

FUNG, Richard. Looking for my Penis: The Eroticized Asian in Gay Video Porn. In BAD OBJECT-CHOICES (ed.). How do I Look? Queer Film and Video. Seattle: Bay Press, 1991, pp. 145-160.

GARDNER, Muriel (ed.). The Wolf-Man by The Wolf-Man. Nova York: Basic Books, 1971. 
GAUGUIN, Paul. Cahier pour Aline / ed. Suzanne Damiron. Paris: Bibliothèque d'art et d'archéologie, 1963.

GAUGUIN, Paul. Noa Noa: Viagem ao Taiti. Rio de Janeiro: Ed. Philobiblion, 1977.

GAUGUIN, Paul. The Writings of a Savage / trad. Eleanor Levieux, ed. Daniel Guérin. Nova York: The Viking Press, 1978.

GAUGUIN, Paul. The Intimate Journals of Paul Gauguin. Londres: Routledge, 1985a.

GAUGUIN, Paul. Noa Noa / trad. Nicholas Wadley. Oxford: Phaidon, 1985b.

GAUGUIN, Paul. Resposta a Strindberg. In Chipp, H. B. Teorias da arte moderna / trad. Antonio de Pádua Danesi, Mônia Stahel. São Paulo: Martins Fontes, 1996.

GILMAN, Sander L. Difference and Pathology: Stereotypes of Sexuality, Race, and Madness. Nova York: Ithaca, 1985. 
GILMAN, Sander L. Black Bodies, White Bodies: Toward an Iconography of Female Sexuality in Late Nineteenth-Century Art, Medicine, and Literature.

Critical Inquiry, vol. 12, outono de 1985, pp. 204-242.

JONES, Ernest. Papers on Psycho-Analysis. Boston: Beacon Press, 1961.

KOVEL, Joel. White Racism: A Psychohistory. Nova York: Columbia University Press, 1984.

KRAUSS, Rosalind. The Motivation of the Sign. In ZELEVANSKY, Lynn. Picasso and Braque: A Symposium. Nova York: Museum of Modern Art, 1992, pp. 261-286.

KRISTEVA, Julia. Powers of Horror / trad. para o inglês de Leon S. Roudiez. Nova York: Columbia University Press, 1982.

LAPLANCHE, Jean; PONTALIS, Jean-Bertrand. Vocabulário de Psicanálise / trad. Pedro Tamem. São Paulo: Martins Fontes, 1991.

LÉVI-STRAUSS, Claude. A busca do poder. In LÉVI-STRAUSS, Claude. Tristes trópicos / trad. Rosa Freire Aguiar. São Paulo: Companhia das Letras, 1996, pp. 34-44.

LLOYD, Jill. German Expressionism: Primitivism and Modernity. New Haven: Yale University Press, 1991. 
MALRAUX, André. Picasso's Mask / trad. para o inglês por June Guicharnaud e Jacques Guicharnaud. Londres: Macdonald and Jane's, 1976, pp. 10-11.

MONTROSE, Louis. The Work of Gender in the Discourse of Discovery. Representations, n. 33, inverno de 1991, pp. 1-41.

MORRISON, Toni. Playing in the Dark: Whiteness and the Literary Imagination. Cambridge: Harvard University Press, 1992.

NOCHLIN, Linda. The Imaginary Orient. Art in America, vol. 71, maio de 1983, pp. 118-131, 187-191.

RICHON, Olivier. Representation, the Harem and the Despot. Block, vol. 10, 1985, pp. 34-41.

RUBIN, William. From Narrative to "Iconic" in Picasso: The Buried Allegory in Bread and Fruitdish on a Table and the Role of Les Demoiselles d'Avignon. The Art Bulletin, vol. 65, n. 4, 1983, pp. 615-649.

SOLOMON-GODEAU, Abigal. Going Native: Paul Gaugin and the Invention of Primitivist Modernism. Art in America, vol. 77, julho de 1989, pp. 118-129, 161.

STEINBERG, Leo. The Philosophical Brother. October, n. 44, primavera de 1988, pp. 7-74. 
STRINDBERG, August. Carta a Gauguin. In Chipp, H. B. Teorias da arte moderna / trad. Antonio de Pádua Danesi, Mônia Stahel. São Paulo: Martins Fontes, 1996, pp. 76-9.

WHITE, Hayden. 0 tema do nobre selvagem como fetiche. In WHITE, Hayden. Trópicos do Discurso: Ensaios Sobre a Crítica da Cultura / trad. Alípio Correia de Franca Neto. São Paulo: Editora da Universidade de São Paulo, 1994, pp. 203-218.

WOLLEN, Peter. Fashion/ Orientalism/ the Body. New Formations, n. 1, primavera de 1987, pp. 5-33.

WOLLHEIM, Richard. Painting as an Art. Nova Jersey: Princeton University Press, 1987.

WORRINGER, Wilhelm. Abstraction and Empathy / trad. para o inglês Michael Bullock. Londres: Routledge and Kegan Paul, 1953. 
Hal Foster é professor de Arte e Arqueologia na Universidade de Princeton, nos Estados Unidos. Publica textos regularmente em periódicos como October, do qual também é coeditor, na revista Artforum e na The London Review of Books. Entre seu livros destacam-se títulos como 0 retorno do real (Cosac Naify, 2014, $1^{\text {a }}$ ed), Complexo arte-arquitetura (Cosac Naify, 2015, 1ª ed), The First Pop Age: Painting and Subjectivity in the Art of Hamilton, Lichtenstein, Warhol, Richter, and Ruscha (Princeton University Press, 2012) e o mais recente 0 que vem depois da farsa? Arte e crítica em tempos de debate (Ubu, 2021, $1^{\mathrm{a}} \mathrm{ed}$ ). 
Janaína Nagata Otoch é doutoranda e mestre em História, Teoria e Crítica de Arte no Programa de Pós-Graduação em Artes Visuais da Escola de Comunicações e Artes da Universidade de São Paulo (ECA-USP), onde defendeu a dissertação Visualidade e sexualidade em Las Meninas, de Picasso, e na obra madura do artista (19571972), realizada com apoio da Fundação de Amparo à Pesquisa do Estado de São Paulo (FAPESP).

Paula Mermelstein Costa é mestranda em História, Teoria e Crítica de Arte no Programa de Pós-Graduação em Artes Visuais da Universidade de São Paulo (USP) e graduada em Cinema e Audiovisual na Universidade Federal Fluminense (UFF). É também editora e redatora da Revista Limite, publicação trimestral de ensaios e crítica de arte. 